\title{
Glucose-Based Fluorinated Surfactants as Additives for the Crystallization of Membrane Proteins: Synthesis and Preliminary Physical-Chemical and Biochemical Characterization
}

\author{
Moheddine Wehbie, Ilham Bouchemal, Anaïs Deletraz, Eva Pebay-Peyroula, Cécile Breyton, \\ Christine Ebel, and Grégory Durand*
}

Cite This: ACS Omega 2021, 6, 24397-24406

Read Online

Fluorinated analog of $n$-octyl- $\beta$-D-glucopyranoside

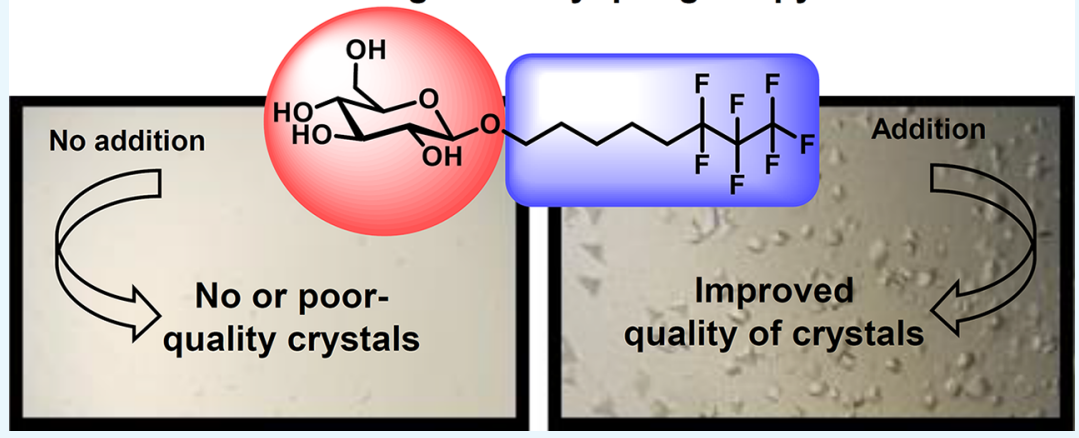

ABSTRACT: We report herein the synthesis of a series of fluorinated surfactants with a glucose moiety as a polar head group and whose alkyl chain was varied in length and in fluorine/hydrogen ratio. They were synthesized in two or four steps in 20 to $50 \%$ overall yields allowing gram-scale synthesis. Their solubility in water is between 0.2 and $13.8 \mathrm{~g} / \mathrm{L}$, which indicates low water solubility. Two derivatives of the series were found to form micelles in water at $\sim 11 \mathrm{mM}$. Their hydrophilic-lipophilic balance was determined both by Griffin's and Davies' methods; they may exhibit a "harsh" character toward membrane proteins. This, combined with their low water solubility, suggest that they could advantageously be used in detergent mixtures containing a "mild" detergent. Finally, the potency of one of the derivatives, $\mathrm{F}_{3} \mathrm{H}_{5}-\beta$-Glu, to act as an additive for the crystallization of AcrB was evaluated in detergent mixtures with $n$-dodecyl- $\beta$-D-maltopyranoside (DDM). Among the six crystallization conditions investigated, adding $\mathrm{F}_{3} \mathrm{H}_{5}-$ $\beta$-Glu improved the crystallization for three of them, as compared to control drops without additives. Moreover, preliminary tests with other compounds of the series showed that none of them hampered crystallization and suggested improvement for three of them. These novel glucose-based fluorinated detergents should be regarded as potential additives that could be included in screening kits used in crystallization.

\section{INTRODUCTION}

Elucidating structures of membrane proteins (MPs), known to be among major drug targets, still remains a challenge. Progresses in various fields, diversification of hosts for protein expression, emergence of novel detergents, ${ }^{1}$ new approaches in sample preparation like incorporation in nanodiscs, ${ }^{2}$ and crystallization in lipidic cubic phases, ${ }^{3}$ combined with functional and biophysical approaches, increased drastically the number of membrane proteins that are amenable to crystallography and cryoelectron microscopy (cryoEM). ${ }^{4}$ However, a large number of membrane proteins are still unstable or not sufficiently soluble in artificial amphiphilic environments, leading to inhomogeneous solutions. Stability and homogeneity of the protein solution are also needed when forming nanodiscs used in cryoEM or when incorporating proteins into lipidic cubic phases for crystallization. In addition, crystallization of membrane proteins using the vapor diffusion method relies on the behavior of a ternary mixture of water, detergent, and precipitant (for review see ref 5 and references herein). Crystallization is known to be favored while approaching the consolution boundary above which a phase separation appears. Getting close to the boundary favors interactions between detergent micelles and thus between protein-detergent complexes.

Received: May 17, 2021

Accepted: July 27, 2021

Published: September 16, 2021 
Scheme 1. Synthesis of Glucose-Based Fluorinated Derivatives

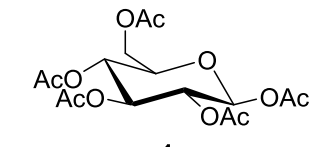

1
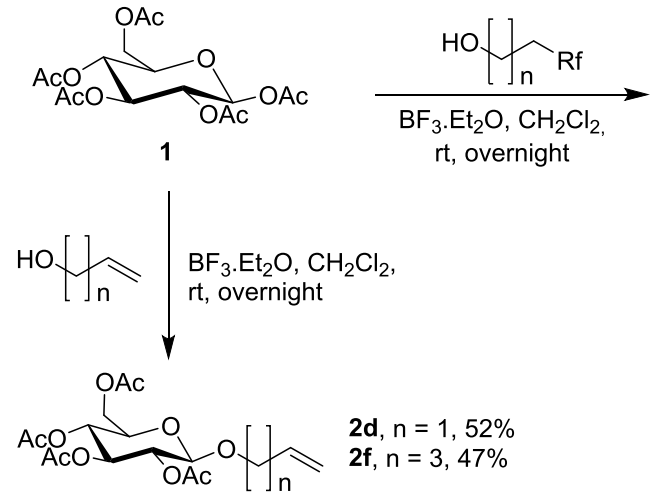

Rf-I

$1 \mathrm{M} \mathrm{BEt}_{3} /$ Hexane

$\mathrm{CH}_{2} \mathrm{Cl}_{2}$, air, rt, $2 \mathrm{~h}$

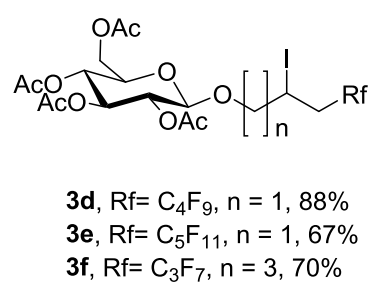

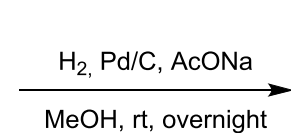
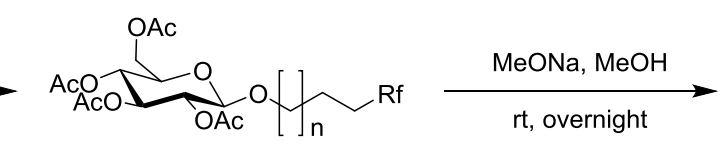

4d, $R f=C_{4} F_{9}, n=1,88 \%$

4e, $\mathrm{Rf}=\mathrm{C}_{5} \mathrm{~F}_{11}, \mathrm{n}=1,70 \%$

4f, $R f=\mathrm{C}_{3} \mathrm{~F}_{7}, \mathrm{n}=3,69 \%$

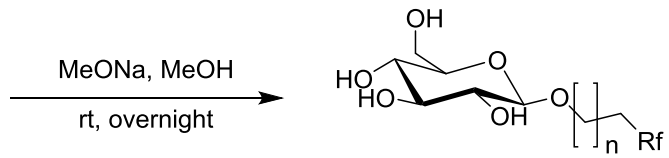

3a, $\mathrm{Rf}=\mathrm{C}_{3} \mathrm{~F}_{7}, \mathrm{n}=2,92 \%$

3b, $\mathrm{Rf}=\mathrm{C}_{4} \mathrm{~F}_{9}, \mathrm{n}=1,93 \%$

3c, $\mathrm{Rf}=\mathrm{C}_{6} \mathrm{~F}_{13}, \mathrm{n}=1,93 \%$
Sugar-based detergents have been the most widely used class of detergents for structural studies on MPs. The two maltosebased $n$-dodecyl- $\beta$-D-maltopyranoside (DDM) and $n$-decyl- $\beta$ D-maltopyranoside (DM) have been used for the determination of about half of the deposited structures of MPs in the Protein Data Bank (PDB). Including also the two glucosebased $n$-octyl- $\beta$-D-glucopyranoside (OG) and $n$-nonyl- $\beta$-Dglucopyranoside (NG) in the listing makes the number of deposited structures around two-thirds, demonstrating the vast use of sugar-based detergents. ${ }^{6}$ Over the last decade, there has been a growing number of examples where chemical additives or secondary detergents were successfully used for the crystallization of MPs. ${ }^{1,7}$ Additives are known to play an important role as they modulate the behavior of the proteindetergent complex. This was already observed in the crystallization of the first membrane protein that led to structure elucidation ${ }^{8}$ and since then about one-third of integral MPs were crystallized in a mixture of detergents. As the effect of an additive will depend on the protein and the chemical nature of all of the compounds, in particular the detergent, and their concentrations, none of the additives is expected to be universal. Increasing the number of additives that showed crystallization improvement even in a limited number of cases is therefore of interest.

A tentative rationalization in the selection and design of detergents for MP crystallization has been proposed by Breibeck and Rompel. ${ }^{1}$ The concept of hydrophilic-lipophilic balance (HLB) allows to classify common detergents into "harsh" and "mild" groups. While harsh detergents are usually preferred to extract MPs because of their propensity to disrupt lipid bilayers, they are often exchanged with "milder" detergents in which the target proteins are more protected against denaturation. Harsh detergents with shorter alkyl chains such as OG are prone to favor crystal contacts and thus yield crystals diffracting to a higher resolution but often increase protein denaturation. By contrast, fluorinated surfactants exhibit rather limited miscibility with lipids and lipid cofactors and therefore can be considered as mild stabilizing detergents, particularly for fragile MPs (for a general review see ref 9). However, despite their well-recognized "mildness", recent findings demonstrated that fluorinated surfactants can also act as solubilizing agents and extract MPs. ${ }^{10-13}$ Fluorinated surfactants have also been successfully used to reconstitute MPs in the artificial bilayer. ${ }^{14,15}$ Mixtures of fluorinated and hydrogenated surfactants lead to various micellar organizations, depending on the molecule type and concentration. $^{16,17}$ It is thus expected that fluorinated surfactants affect membrane protein crystallization, even if benefits are hardly predictable.

Some original high-resolution structures of membrane proteins were obtained with the help of the commercially available fluorinated surfactant $1 \mathrm{H}, 1 \mathrm{H}, 2 \mathrm{H}, 2 \mathrm{H}$-perfluorooctyl)$\beta$-D-maltopyranoside $\left(\mathrm{F}_{6} \mathrm{OM}\right)$ or its phosphocholine analogue ( $\left.\mathrm{F}_{6} \mathrm{OPC}\right)$. They were generally selected from a screen of secondary detergents as additives (at $\sim 0.1 \%$ while the hydrogenated detergent is in $\%$ amounts) to improve crystal quality. For example, addition of $\mathrm{F}_{6} \mathrm{OM}$ improved the diffraction from 5 to $4 \AA$ of crystals of RibU, the $S$ component of the ECF-type riboflavin transporter of Staphylococcus aureus. ${ }^{18} \mathrm{~F}_{6} \mathrm{OM}$ was also used as an additive to crystallize the membrane domain of the electron transport chain complex I of Escherichia coli, leading to a structure at $3.9 \AA$ resolution, ${ }^{19}$ and $\mathrm{F}_{6} \mathrm{OPC}$ as an additive for the crystallization of the entire complex I of Tetraopes thermophilus, leading to a structure at $3.3 \AA$ resolution. ${ }^{20}$ Crystals of mitochondrial cytochrome $c$ oxidase from bovine heart, $\mathrm{CcO}$, alone ${ }^{21}$ or in complex with cytochrome $c^{22}$ were crystallized using $\mathrm{F}_{6} \mathrm{OM}$ as the main detergent, allowing structure determination at 1.77 and $2.0 \AA$, respectively. $\mathrm{F}_{6} \mathrm{OPC}$ is also indicated as an additive improving the crystal quality of a couple of soluble proteins. ${ }^{23,24}$ 
In this work, we focused our attention on the design and the synthesis of OG analogues bearing a partially fluorinated chain as additives for crystallization. We report herein the synthesis of a series of glucose-based fluorinated surfactants whose alkyl chain was varied in length and in fluorine/hydrogen ratio. The solubility in water of the series as well as their ability to assemble into micelles was further investigated and was correlated to their hydrophilic-lipophilic balance (HLB). Finally, their potency to act as additives for the crystallization of AcrB was evaluated in detergent mixtures with DDM.

\section{RESULTS AND DISCUSSION}

Synthesis. The fluorinated glucoside derivatives were synthesized, as illustrated in Scheme 1, using two different synthetic pathways depending on the availability of the fluorinated alcohols (Rf-OH). The first synthetic pathway involves the glycosylation of an excess of commercially available fluorinated alcohols ( $\mathrm{Rf}-\mathrm{OH}, 1.5$ equiv) with $\beta$-Dglucose pentaacetate in the presence of $\mathrm{BF}_{3} \cdot \mathrm{Et}_{2} \mathrm{O}{ }^{25}$ The crude compounds were purified by flash chromatography to afford pure compounds $2 \mathrm{a}-\mathbf{c}$ in $45-53 \%$ yields. The $\beta$-anomeric configuration of the three compounds was confirmed by ${ }^{1} \mathrm{H}$ and ${ }^{13} \mathrm{C}$ NMR spectra. The acetyl protective groups were then removed using a catalytic amount of $\mathrm{MeONa}$ in $\mathrm{MeOH}$ to afford the desired compounds $3 a-c$ in $92-93 \%$ yields after silica gel flash chromatography purification.

The other derivatives $\mathbf{5} \mathbf{d}-\mathbf{f}$ were prepared in four steps. This synthetic route relies on the insertion of an allyl group onto which fluorinated chains were further grafted. First, the allylbased compounds $\mathbf{2 d}$ and $\mathbf{2 f}$ were obtained in $\sim 50 \%$ yield from $\beta$-D-glucose pentaacetate by glycosylation of allyl alcohol or 4-penten-1-ol. The double bond of the obtained compounds $\mathbf{2 d}$ and $\mathbf{2 f}$ was then subjected to a free radical reaction with perfluoroalkyl iodide in the presence of $1 \mathrm{M} \mathrm{BEt}_{3}$ in hexane and oxygen, using the methodology described by Takeyama and co-workers. ${ }^{26}$ Under these conditions, the compounds $3 \mathbf{d}-\mathbf{f}$ were obtained in good yields, ranging from $67 \%$ for compound $3 \mathrm{e}$ to $88 \%$ for compound $3 \mathrm{~d}$. The addition of the fluoroalkyl chains on the double bond was confirmed by ${ }^{1} \mathrm{H}$ and ${ }^{13} \mathrm{C}$ NMR, which showed the disappearance of the signals corresponding to the $\mathrm{CH}_{2}$ and $\mathrm{CH}$ of the double bond and the formation of new signals related to the $\mathrm{CH}-\mathrm{I}$ group. The iodide group of compounds $\mathbf{3} \mathbf{d}-\mathbf{f}$ was then reduced under a $\mathrm{H}_{2}$ atmosphere in the presence of $\mathrm{Pd} / \mathrm{C}$ as the catalyst and led to compounds $\mathbf{4 d}-\mathbf{f}$ in $69-88 \%$ yields. Finally, the acetyl groups were removed using a catalytic amount of $\mathrm{MeONa}$ in $\mathrm{MeOH}$ to afford the desired compounds $\mathbf{5 d - f}$ in $84-92 \%$ yields after silica gel flash chromatography purification. All of the fluorinated detergents were freeze-dried after purification.

Physical-Chemical Characterization. For the sake of clarity in the discussion, the fluorinated surfactants were denoted $\mathrm{F}_{n} \mathrm{H}_{m}-\beta$-Glu, where $n$ and $m$ indicate, respectively, the number of fluorinated and hydrogenated carbons within the hydrophobic chain and $-\beta$-Glu indicates the glucose polar head with a $\beta$ configuration of the anomeric carbon.

Water Solubility. The water solubility of the $\mathrm{F}_{n} \mathrm{H}_{m}-\beta$-Glu series was determined by turbidity measurement of the aqueous solution using a CrystalEYES system. Figure 1 depicts the evolution of the turbidity of aqueous solutions of $\mathrm{F}_{n} \mathrm{H}_{m}-\beta$ Glu at varying concentrations. As we can see, at a low concentration, the turbidity remains constant over the first range of concentrations at about 0.5 to 1.0 Nephelometric Turbidity Units (NTU) and then a break is observed and the

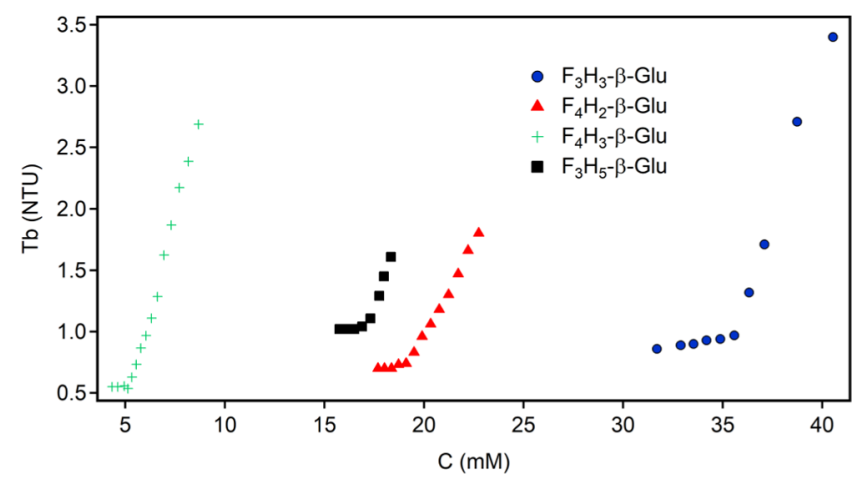

Figure 1. Turbidity measurement of an aqueous solution of $\mathrm{F}_{3} \mathrm{H}_{3}-\beta$ Glu (3a), $\mathrm{F}_{4} \mathrm{H}_{2}-\beta$-Glu (3b), $\mathrm{F}_{4} \mathrm{H}_{3}-\beta$-Glu (5d), and $\mathrm{F}_{3} \mathrm{H}_{5}-\beta$-Glu (5f) at $25{ }^{\circ} \mathrm{C}$.

turbidity starts to increase steadily with the concentration. The linear fitting of the two sets of points led to a concentration value that was taken as the water solubility limit of the derivatives. The values are reported in Table 1 and they range from 5.2 to $36.0 \mathrm{mM}$, demonstrating the poor water solubility of the compounds. For $\mathrm{F}_{6} \mathrm{H}_{2}-\beta$-Glu and $\mathrm{F}_{5} \mathrm{H}_{3}-\beta$-Glu, the water solubility could not be determined by this technique as $1 \mathrm{mM}$ solutions were already turbid. For these two compounds, a visual determination was conducted. A saturated solution was first prepared and then diluted until a clear limpid solution was observed.

Surface Tension Measurement. The surface tension activity of aqueous solutions of $\mathrm{F}_{n} \mathrm{H}_{m}-\beta$-Glu was next investigated by the Wilhelmy plate method. Since surface tension requires large volumes of stock solution at $\sim 3-4$ times the CMC and therefore needs large amounts of surfactants when the CMC is expected to be high, we did not test the most hydrophilic derivatives $\mathrm{F}_{3} \mathrm{H}_{3}-\beta$-Glu, $\mathrm{F}_{3} \mathrm{H}_{5}-\beta$-Glu, and $\mathrm{F}_{4} \mathrm{H}_{2}-\beta$-Glu. Stock solutions of $\mathrm{F}_{4} \mathrm{H}_{3}-\beta$-Glu, $\mathrm{F}_{5} \mathrm{H}_{3}-\beta$-Glu, and $\mathrm{F}_{6} \mathrm{H}_{2}-\beta$-Glu were prepared at $4.3,0.73$, and $0.32 \mathrm{mM}$, respectively. The surface tension of these stock solutions was measured, and as seen in Figure 2 for the three derivatives tested, a quite low surface tension was measured ranging from 20.8 and $27.2 \mathrm{mN} / \mathrm{m}$. However, the constant addition of a fixed amount of water failed to show any plateau in the surface tension. Instead, a regular increase in the surface tension was observed with the dilution, demonstrating a surface activity of these components. This indicates that no micelles can be formed by these three compounds due to their limited water solubility. This suggests that precipitation of the derivatives occurs before reaching the "theoretical" CMC.

${ }^{19} \mathrm{~F}$ Nuclear Magnetic Resonance. For the more watersoluble derivatives, $\mathrm{F}_{4} \mathrm{H}_{2}-\beta$-Glu and $\mathrm{F}_{3} \mathrm{H}_{5}-\beta$-Glu, the CMC could be measured by ${ }^{19} \mathrm{~F}$ NMR, as shown in Figure 3. Indeed, ${ }^{19} \mathrm{~F}$ NMR is an appropriate method for surfactants with high $\mathrm{CMC}$ as it requires low volumes of stock solution. We followed the signal of the $\mathrm{CF}_{3}$ group and plotted the variation in chemical shift as a function of the surfactant concentration to derive the $\mathrm{CMC}$ value. The values of $\mathrm{CMC}$ are reported in Table 1 and show that the CMC values of $\mathrm{F}_{4} \mathrm{H}_{2}-\beta$-Glu and $\mathrm{F}_{3} \mathrm{H}_{5}-\beta$-Glu are very close to their water solubility, indicating that resorting to surface tension measurements to confirm the CMC would have been difficult. This clearly contrasts with the fully hydrogenated OG whose CMC ranges from 19 to $25 \mathrm{mM}$ depending on the techniques used to evaluate it and whose water solubility is above $100 \mathrm{~g} / \mathrm{L}$. 
Table 1. Water Solubility, CMC, and Griffin (HLBG) and Davies (HLBD) Hydrophilic-Lipophilic Balance of the Synthesized Surfactants

\begin{tabular}{|c|c|c|c|c|c|c|c|c|}
\hline \multirow[b]{2}{*}{ compound } & \multirow[b]{2}{*}{$\mathrm{F}_{n} \mathrm{H}_{m}-\beta-\mathrm{Glu}$} & \multirow[b]{2}{*}{$M(\mathrm{~g} / \mathrm{mol})$} & \multicolumn{2}{|c|}{ water solubility } & \multicolumn{2}{|c|}{$\mathrm{CMC}$} & \multirow[b]{2}{*}{ HLBG } & \multirow[b]{2}{*}{ HLBD } \\
\hline & & & $\mathrm{mM}$ & $\mathrm{g} / \mathrm{L}$ & $\mathrm{mM}$ & $\mathrm{g} / \mathrm{L}$ & & \\
\hline $3 a$ & $\mathrm{~F}_{3} \mathrm{H}_{3}-\beta$-Glu & 390.3 & 35.3 & 13.8 & $c$ & \multirow{5}{*}{$4.6^{d}$} & 9.2 & 9.4 \\
\hline $3 b$ & $\mathrm{~F}_{4} \mathrm{H}_{2}-\beta$-Glu & 426.2 & 19.3 & 8.2 & $10.9^{d}$ & & 8.4 & 9.0 \\
\hline $3 c$ & $\mathrm{~F}_{6} \mathrm{H}_{2}-\beta-\mathrm{Glu}$ & 526.3 & $\approx 0.3^{a}$ & $\approx 0.2^{a}$ & \multirow[t]{2}{*}{$e$} & & 6.8 & 7.3 \\
\hline $5 d$ & $\mathrm{~F}_{4} \mathrm{H}_{3}-\beta$-Glu & 440.3 & 5.2 & 2.3 & & & 8.1 & 8.6 \\
\hline $5 e$ & $\mathrm{~F}_{5} \mathrm{H}_{3}-\beta-\mathrm{Glu}$ & 490.3 & $\approx 0.7^{a}$ & $\approx 0.3^{a}$ & $e$ & & 7.3 & 7.7 \\
\hline $5 f$ & $\mathrm{~F}_{3} \mathrm{H}_{5}-\beta$-Glu & 418.3 & 17.0 & 7.1 & $11.7^{d}$ & $4.9^{d}$ & 8.5 & 8.5 \\
\hline \multicolumn{2}{|c|}{$n$-octyl- $\beta$-D-glucopyranoside } & 292.4 & $>342^{b}$ & $>100^{b}$ & $25^{f}$ & $7.3^{f}$ & $12.3(11.2)^{g}$ & 9.7 \\
\hline
\end{tabular}

${ }^{a}$ Visual determination (a limpid solution was observed). ${ }^{b}$ Data from commercial sources. ${ }^{c}$ Not determined. ${ }^{d}$ Determined by ${ }^{19} \mathrm{~F}$ NMR. ${ }^{e}$ Measured by surface tension measurement; no micelle formation. ${ }^{f}$ Measured by surface tension measurement; data from ref $27 .{ }^{g}$ Data from ref 1 .

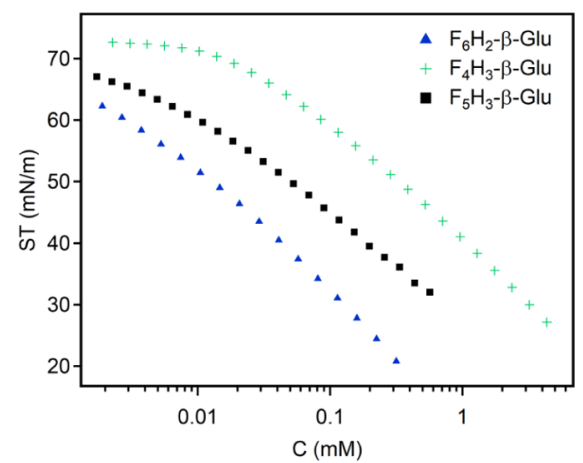

Figure 2. Surface tension measurement of $\mathrm{F}_{6} \mathrm{H}_{2}-\beta$-Glu (3c), $\mathrm{F}_{4} \mathrm{H}_{3}-\beta$ Glu (5d), and $\mathrm{F}_{5} \mathrm{H}_{3}-\beta$-Glu (5e) at $25{ }^{\circ} \mathrm{C}$.

Hydrophilic-Lipophilic Balance (HLB). The hydrophiliclipophilic balance (HLB) introduced by Griffin is a valuable reference to characterize a detergent. It is calculated from the ratio of the hydrophilic vs total molar mass of the surfactant. $^{28,29}$ Later, Davies suggested a method based on the nature of chemical groups of the molecule. ${ }^{30}$ The advantage of this latter method is that it takes into account the effect of stronger and weaker hydrophilic groups as well as the contribution of the fluorinated carbons. ${ }^{3,32}$ The higher accuracy of composition-calculated HLB over the Griffin method has been discussed in the literature. ${ }^{33}$ The HLB of our derivatives was calculated according to both the Griffin (HLBG) and the Davies (HLBD) equations; the values are presented in Table 1 . Since it is now admitted that the first methylene of the chain connected to the polar head group is part of the hydration sphere, it was excluded from the calculation of the HLBD. ${ }^{1}$ The concept of hydrophilic- lipophilic balance allows to classify common detergents into harsh and mild groups and its use in the selection and design of detergents for MP crystallization has been reviewed and discussed by Breibeck and Rompel. ${ }^{1}$ In the literature, the detergents that have been successfully used for the stabilization and/or crystallization of MPs have moderate HLBG values near 12 , ensuring long-time compatibility with the protein. ${ }^{1}$ However, the "harshness" of the detergent depends on other parameters. Indeed, detergents with a harsh character usually feature small and/or charged head groups and short alkyl chains. For example, the dodecyl maltoside DDM with an HLBG value of 13.4 (12.3 from ref 1 ) is classified as a mild detergent, while the octyl glucoside OG with an HLBG value of 12.2 ( 11.2 from ref 1 ) belongs to the harsh series. Resorting to the Davies method shows stronger differences in the HLB values of the fully hydrogenated detergents. Indeed, we calculated values of 13.3 and 9.7 for DDM and OG, respectively. With regard to our fluorinated series, a very good agreement was noted between the two methods, with HLB values being between 7 and 9. Thus, our fluorinated derivatives should be considered harsh detergents. The use of a detergent mixture containing a mild detergent in combination with our glucose-based detergents was therefore chosen so as to investigate their potency in MP crystallization.

We tested all of the compounds as additives for the crystallization of AcrB, an efflux pump located in the inner membrane of E. coli. AcrB is easy to purify and crystallize. Several structures are deposited in the PDB. Interestingly, large screening kits lead to hits with several crystallization conditions, only a few of them are amenable to high-resolution diffraction. This opens a large field of different conditions to explore. We used the 96 conditions of the MemGold screen
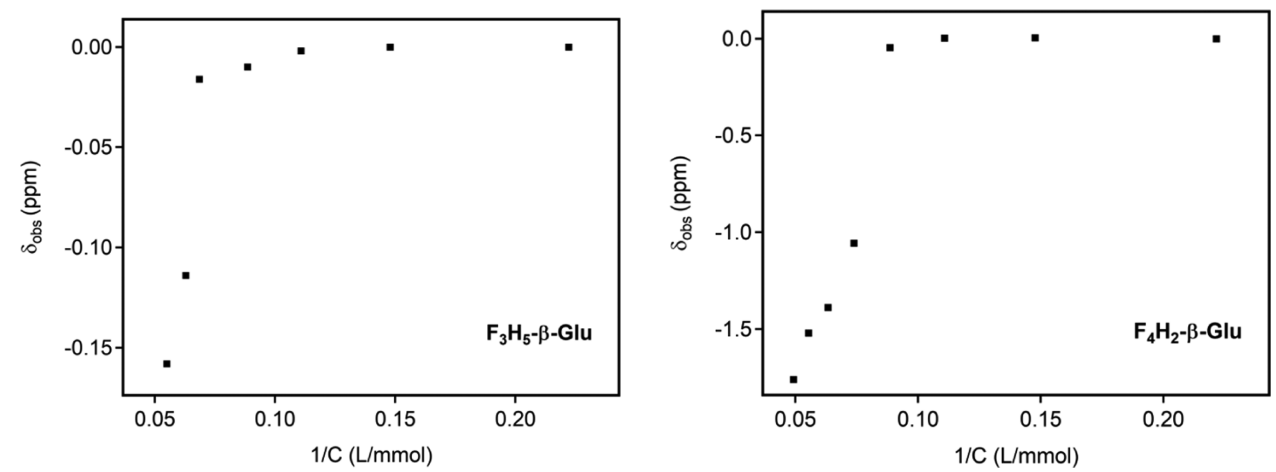

Figure 3. Determination of the $\mathrm{CMC}$ of $\mathrm{F}_{3} \mathrm{H}_{5}-\beta$-Glu (5f) and of $\mathrm{F}_{4} \mathrm{H}_{2}-\beta$-Glu $(3 \mathbf{b})$ by ${ }^{19} \mathrm{~F}$ NMR $(376 \mathrm{MHz})$ at $25{ }^{\circ} \mathrm{C}$. 

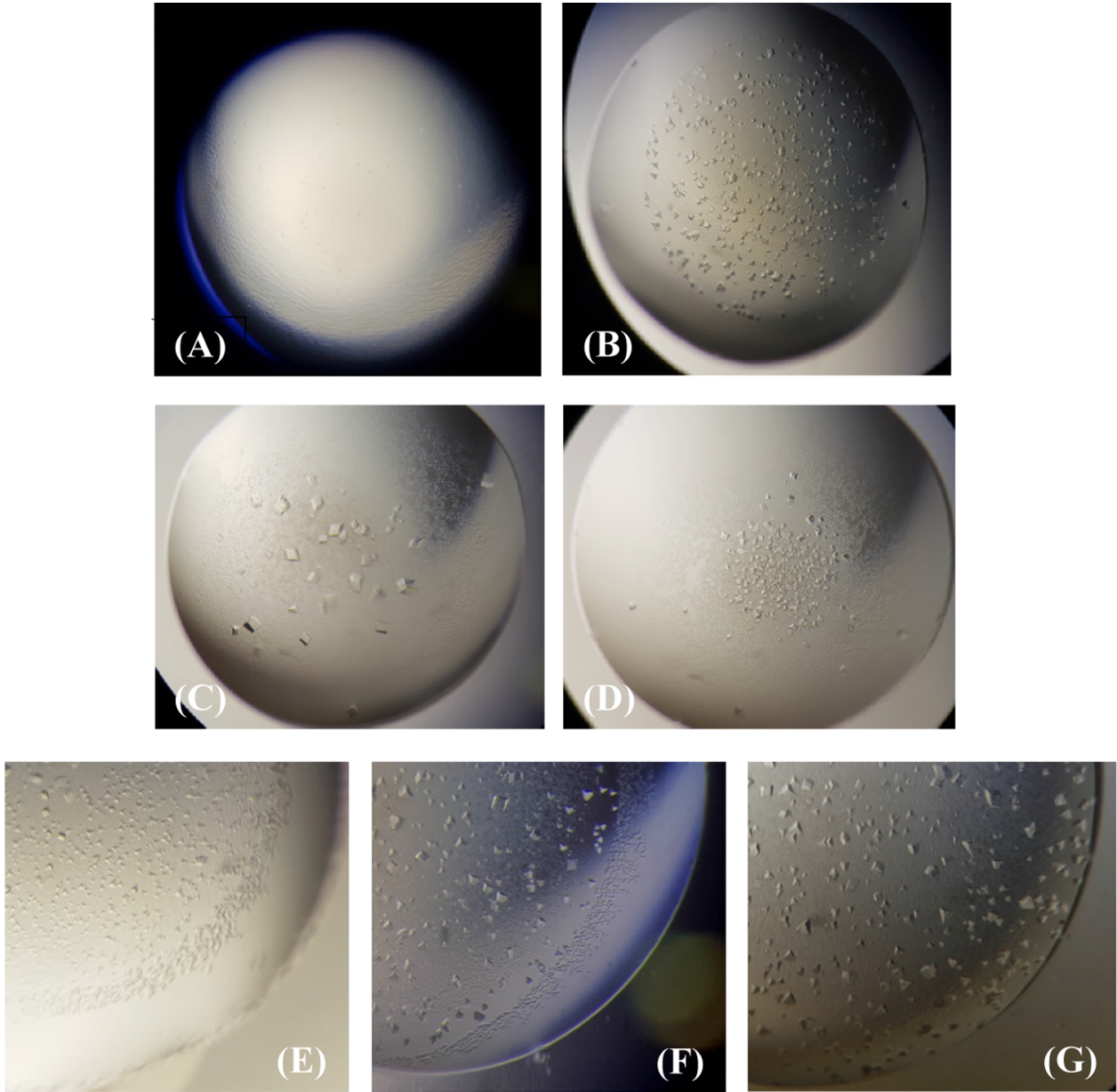

Figure 4. (A) Condition 1, control DDM (0.02\%); (B) condition 1, DDM (0.02\%)- $\mathrm{F}_{3} \mathrm{H}_{5}-\beta$-Glu (0.002\%); (C) condition 4, DDM (0.02\%)- $\mathrm{F}_{3} \mathrm{H}_{5}$ $\beta$-Glu $(0.002 \%)$; (D) condition 4, DDM (0.02\%) $-\mathrm{F}_{3} \mathrm{H}_{5}-\beta$-Glu (0.02\%); (E) condition 5, control DDM (0.02\%); (F) condition 5, DDM (0.02\%)$\mathrm{F}_{3} \mathrm{H}_{5}-\beta$-Glu $(0.002 \%)$; and $(\mathrm{G})$ condition 5, DDM $(0.02 \%)-\mathrm{F}_{3} \mathrm{H}_{5}-\beta$-Glu $(0.02 \%)$.

diluted by two with water. From this screen, we selected up to six crystallization conditions that did not provide the bestlooking crystals, that is, small crystals, poor or different crystal habits, multicrystalline particles, strong nucleation, and phase separation at the edge of crystallization to name but a few.

We reproduced these conditions manually in 24-well crystallization plates using the hanging drop method and added the fluorinated compounds as additives at different concentrations in the presence of a constant concentration of DDM $(0.02 \%)$ and observed whether crystallization was affected. Among the additives tested, $\mathrm{F}_{6} \mathrm{H}_{2^{-}}, \mathrm{F}_{4} \mathrm{H}_{2^{-}}$, and $\mathrm{F}_{3} \mathrm{H}_{3}-\beta$-Glu showed no improvement (but also no negative effect), and $\mathrm{F}_{5} \mathrm{H}_{3}-\mathrm{F}_{4} \mathrm{H}_{3^{-}}$, and $\mathrm{F}_{3} \mathrm{H}_{5}-\beta$-Glu showed improved crystallization. As we performed more experiments with the latter, we focus herein on $\mathrm{F}_{3} \mathrm{H}_{5}-\beta$-Glu. AcrB was incubated with $\mathrm{F}_{3} \mathrm{H}_{5}-\beta$-Glu at different concentrations $(0,0.002,0.02$, and $0.04 \%)$ prior to crystallization. Three protein purifications coming from different membrane preparations were tested and gave converging results. Adding $\mathrm{F}_{3} \mathrm{H}_{5}-\beta$-Glu improved the crystallization for three crystallization conditions $(1,4$, and 5$)$ and did not affect crystallization for the three others as compared to control drops without additives.

For condition 1 , the addition of $0.002 \% \mathrm{~F}_{3} \mathrm{H}_{5}-\beta$-Glu led to the formation of small nicely shaped crystals, whereas the control drop had a gel-like aspect with phase separation (Figure 4A,B). Crystallization with condition 4 was also drastically improved in the presence of $0.002 \% \mathrm{~F}_{3} \mathrm{H}_{5}-\beta$-Glu, going from a precipitate (not shown) to an ensemble of wellshaped crystals (Figure 4C). It has to be noted that a larger amount of additive, $0.02 \%$ (Figure 4D) and $0.04 \%$ (not shown), decreased the benefit of this additive. Although less spectacular, condition 5 is also improved in the presence of $\mathrm{F}_{3} \mathrm{H}_{5}-\beta$-Glu, the control drop exhibiting small crystalline particles that are mostly round-shaped with a few having nice crystal shapes (Figure 4E), while with increasing amounts of $\mathrm{F}_{3} \mathrm{H}_{5}-\beta$-Glu, 0.002 and $0.02 \%$, the shapes of the crystals as well as their sizes are clearly improved (Figure 4F,G). Furthermore, preliminary tests with other compounds of the same family but having different chain lengths or fluorine contents were also tested. None of them hampered crystallization and $\mathrm{F}_{6} \mathrm{H}_{3}-\beta$-Glu, $\mathrm{F}_{5} \mathrm{H}_{3}-\beta$-Glu, and $\mathrm{F}_{4} \mathrm{H}_{3}-\beta$-Glu seemed to improve it (data not shown).

\section{CONCLUSIONS}

In summary, six fluorinated surfactants with a glucose polar head group and whose alkyl chain was varied in length, from six to eight carbon atoms were synthesized. The presence of three to six perfluorinated carbon atoms within the chain significantly hampered the water solubility of the surfactants. Among the series, the two derivatives $\mathrm{F}_{3} \mathrm{H}_{5}-\beta$-Glu and $\mathrm{F}_{4} \mathrm{H}_{3}-\beta$ Glu exhibited a water solubility superior to $7-8 \mathrm{~g} / \mathrm{L}$ and were found to form micelles at $\sim 11 \mathrm{mM} . \mathrm{F}_{3} \mathrm{H}_{5}-\beta$-Glu, which can be 
seen as a fluorinated analogue of $n$-octyl- $\beta$-D-glucopyranoside (OG), improved the crystallization of AcrB in detergent mixtures with DDM. Among the six investigated crystallization conditions, improvement for three of them was observed, while preliminary tests with other surfactants suggest also potential as additives for crystallization. This warrants further investigation of the whole series and may result in the near future in the development of screening kits for crystallization of membrane proteins.

\section{EXPERIMENTAL SECTION}

Synthesis. All starting materials were commercially available and were used without further purification. All solvents were of reagent grade and used as received unless otherwise indicated. Anhydrous solvents were dried by simple storage over activated $4 \AA$ molecular sieves for at least $24 \mathrm{~h}$. Molecular sieves were activated by heating in vacuum. The progress of the reactions was monitored by thin-layer chromatography (60 $\mathrm{F}_{254}$ Merck plates). The compounds were detected either by exposure to ultraviolet light $(254 \mathrm{~nm})$ or by spraying with sulfuric acid (5\% ethanol), followed by heating at $\sim 150{ }^{\circ} \mathrm{C}$. Flash column chromatography was carried out on a silica gel $(40-63 \mu \mathrm{m})$ with a CombiFlash system. ${ }^{1} \mathrm{H}$, ${ }^{13} \mathrm{C}$, and ${ }^{19} \mathrm{~F}$ NMR analyses were performed on a Bruker AC400 at 400, 100, and $375 \mathrm{MHz}$, respectively. Chemical shifts are given in ppm relative to the solvent residual peak as a heteronuclear reference for ${ }^{1} \mathrm{H}$ and ${ }^{13} \mathrm{C}$. The coupling constant $J$ is given in hertz. Abbreviations used for signal patterns are as follows: s, singlet; $d$, doublet; $t$, triplet; q, quartet; m, multiplet; $\mathrm{dd}$, doublet of doublets; and $\mathrm{dt}$, doublet of triplets. Highresolution mass spectrometry (HRMS) was performed on a SYNAPT G2-S (Waters) mass spectrometer equipped with a time-of-flight (TOF) analyzer for $\mathrm{ESI}^{+}$experiments. Milli-Q water (resistivity, $18.2 \mathrm{M} \Omega \mathrm{cm}$; surface tension, $71.45 \mathrm{mN} / \mathrm{m}$ at $25^{\circ} \mathrm{C}$ ) was employed for all physical-chemical experiments.

General Procedure for the Glycosylation Reaction (Compounds 2a-f). Under an argon atmosphere, $\beta$-Dglucose pentaacetate (1.0 equiv) was dissolved in dry $\mathrm{CH}_{2} \mathrm{Cl}_{2}$. At $0{ }^{\circ} \mathrm{C}$, the corresponding alcohol ( 1.5 equiv) was added, followed by the dropwise addition of boron trifluoride diethyl ether complex ( 1.5 equiv). The reaction mixture was stirred at $0{ }^{\circ} \mathrm{C}$ for $2 \mathrm{~h}$ and then at room temperature overnight. After completion of the reaction, $\mathrm{CH}_{2} \mathrm{Cl}_{2}$ was added and the mixture was washed with saturated $\mathrm{NaHCO}_{3}(2 \times)$ and brine $(2 \times)$. The organic layers were collected, dried over anhydrous $\mathrm{Na}_{2} \mathrm{SO}_{4}$, filtered, and concentrated under vacuum. The crude compound was purified by flash chromatography (cyclohexane/AcOEt, 7:3 v/v) to yield the desired compounds 2a-f.

$4^{\prime}, 4^{\prime}, 5^{\prime}, 5^{\prime}, 6^{\prime}, 6^{\prime}, 6^{\prime}$-Heptafluorohexyl- $\beta$-D-2,3,4,6-tetra-Oacetyl-glucopyranoside (2a). 2a was synthesized from $\beta$-Dglucose pentaacetate $(1.50 \mathrm{~g}, 3.85 \mathrm{mmol}), 4,4,5,5,6,6,6$ heptafluorohexan-1-ol (1.62 g, $5.77 \mathrm{mmol})$, and boron trifluoride diethyl ether complex $(0.73 \mathrm{~mL}, 5.77 \mathrm{mmol})$. It was obtained as a white powder $(0.95 \mathrm{~g}, 45 \%) .{ }^{1} \mathrm{H}$ NMR (400 $\left.\mathrm{MHz}, \mathrm{CDCl}_{3}\right): \delta 5.19(\mathrm{~m}, 1 \mathrm{H}), 5.07(\mathrm{~m}, 1 \mathrm{H}), 4.98(\mathrm{dd}, J=9.6$ and $8.0 \mathrm{~Hz}, 1 \mathrm{H}), 4.52(\mathrm{~d}, J=8.0 \mathrm{~Hz}, 1 \mathrm{H}), 4.23(\mathrm{~m}, 1 \mathrm{H}), 4.12$ $(\mathrm{m}, 1 \mathrm{H}), 3.92(\mathrm{~m}, 1 \mathrm{H}), 3.68(\mathrm{~m}, 1 \mathrm{H}), 3.58(\mathrm{~m}, 1 \mathrm{H}), 2.27-$ $1.97(\mathrm{~m}, 14 \mathrm{H}), 1.89(\mathrm{~m}, 2 \mathrm{H}) .{ }^{19} \mathrm{~F} \mathrm{NMR}\left(375 \mathrm{MHz} \mathrm{CDCl}_{3}\right): \delta$ -80.6, -115.4, -127.8. ${ }^{13} \mathrm{C}$ NMR $\left(100 \mathrm{MHz} \mathrm{CDCl}_{3}\right): \delta$ $170.8,170.4,169.5,169.4,100.8,72.9,72.0,71.3,68.5,68.4$, 62.0, 27.4, 20.8, 20.8, 20.7, 20.6. $3^{\prime}, 3^{\prime}, 4^{\prime}, 4^{\prime}, 5^{\prime}, 5^{\prime}, 6^{\prime}, 6^{\prime}, 6^{\prime}$-Nonafluorohexyl- $\beta$ - D-2,3,4,6-tetraO-acetyl-glucopyranoside (2b). $2 \mathbf{b}$ was synthesized from $\beta$-Dglucose pentaacetate $(1.20 \mathrm{~g}, 3.07 \mathrm{mmol}), 3,3,4,4,5,5,6,6,6-$ nonafluorohexan-1-ol (1.22 g, $4.62 \mathrm{mmol})$, and boron trifluoride diethyl ether complex $(0.65 \mathrm{~mL}, 4.61 \mathrm{mmol})$. It was obtained as a white powder (0.93 g, 50\%). ${ }^{1} \mathrm{H}$ NMR (400 $\left.\mathrm{MHz}, \mathrm{CDCl}_{3}\right): \delta 5.19(\mathrm{~m}, 1 \mathrm{H}), 5.06(\mathrm{~m}, 1 \mathrm{H}), 4.98(\mathrm{dd}, J=9.5$ and $8.0 \mathrm{~Hz}, 1 \mathrm{H}), 4.53(\mathrm{~d}, J=8.0 \mathrm{~Hz}, 1 \mathrm{H}), 4.24(\mathrm{~m}, 1 \mathrm{H}), 4.12$ $(\mathrm{m}, 2 \mathrm{H}), 3.83(\mathrm{~m}, 1 \mathrm{H}), 3.72(\mathrm{~m}, 1 \mathrm{H}), 2.41(\mathrm{~m}, 2 \mathrm{H}), 2.09-$ $1.96(\mathrm{~m}, 12 \mathrm{H}) .{ }^{19} \mathrm{~F}$ NMR (375 $\left.\mathrm{MHz}, \mathrm{CDCl}_{3}\right): \delta-81.1$, $-113.6,-124.6,-126.0 .{ }^{13} \mathrm{C} \mathrm{NMR}\left(100 \mathrm{MHz}, \mathrm{CDCl}_{3}\right): \delta$ $170.7,170.3,169.5,169.4,101.0,72.7,72.1,71.1,68.5,62.0$, $31.5,20.7,20.7,20.5$.

$3^{\prime}, 3^{\prime}, 4^{\prime}, 4^{\prime}, 5^{\prime}, 5^{\prime}, 6^{\prime}, 6^{\prime}, 7^{\prime}, 7^{\prime}, 8^{\prime}, 8^{\prime}, 8^{\prime}-$ Tridecafluorooctyl- $\beta$-D2,3,4,6-tetra-O-acetyl-glucopyranoside (2c). 2c was synthesized from $\beta$-D-glucose pentaacetate $(1.25 \mathrm{~g}, 3.20 \mathrm{mmol})$, $3,3,4,4,5,5,6,6,7,7,8,8,8$-tridecafluorooctan-1-ol (1.45 g, 4.0 $\mathrm{mmol})$, and boron trifluoride diethyl ether complex (0.60 $\mathrm{mL}, 4.80 \mathrm{mmol})$. It was obtained as a white powder $(1.50 \mathrm{~g}$, $53 \%) .{ }^{1} \mathrm{H}$ NMR (400 MHz, $\left.\mathrm{CDCl}_{3}\right): \delta 5.19(\mathrm{~m}, 1 \mathrm{H}), 5.07(\mathrm{~m}$, $1 \mathrm{H}), 4.98(\mathrm{~m}, 1 \mathrm{H}), 4.53(\mathrm{~m}, 1 \mathrm{H}), 4.25(\mathrm{~m}, 1 \mathrm{H}), 4.12(\mathrm{~m}, 2 \mathrm{H})$, $3.82(\mathrm{~m}, 1 \mathrm{H}), 3.70(\mathrm{~m}, 1 \mathrm{H}), 2.41(\mathrm{~m}, 2 \mathrm{H}), 2.14-1.91(\mathrm{~m}$, 12H). ${ }^{19} \mathrm{~F}$ NMR $\left(375 \mathrm{MHz}, \mathrm{CDCl}_{3}\right): \delta-81.0,-113.4$, $-122.0,-123.0,-123.7,-126.3 .{ }^{13} \mathrm{C}$ NMR (100 MHz, $\left.\mathrm{CDCl}_{3}\right): \delta 170.7,170.4,169.5,101.0,72.8,72.1,71.1,68.5$, 62.0, 31.6, 20.7, 20.6, 20.6, 20.4.

Allyl- $\beta$-D-2,3,4,6-tetra-O-acetyl-glucopyranoside (2d). $2 \mathrm{~d}$ was synthesized from $\beta$-D-glucose pentaacetate $(3.00 \mathrm{~g}, 7.68$ $\mathrm{mmol})$, allyl alcohol (0.67 g, $11.53 \mathrm{mmol})$, and boron trifluoride diethyl ether complex $(1.5 \mathrm{~mL}, 11.53 \mathrm{mmol})$. It was obtained as a white powder (1.54 g, 52\%). ${ }^{1} \mathrm{H}$ NMR (400 $\left.\mathrm{MHz}, \mathrm{CDCl}_{3}\right): \delta 5.84(\mathrm{~m}, 1 \mathrm{H}), 5.30-5.15(\mathrm{~m}, 3 \mathrm{H}), 5.12-4.97$ $(\mathrm{m}, 2 \mathrm{H}), 4.54(\mathrm{~d}, J=8.0 \mathrm{~Hz}, 1 \mathrm{H}), 4.32(\mathrm{~m}, 1 \mathrm{H}), 4.24(\mathrm{~m}$, $1 \mathrm{H}), 4.16-4.04(\mathrm{~m}, 2 \mathrm{H}), 3.67(\mathrm{~m}, 1 \mathrm{H}), 2.12-1.95(\mathrm{~m}, 12 \mathrm{H})$. ${ }^{13} \mathrm{C}$ NMR (100 MHz, $\left.\mathrm{CDCl}_{3}\right): \delta 170.8,170.4,169.5,169.4$, 133.4, 117.7, 99.7, 73.0, 71.9, 71.4, 70.1, 68.6, 62.1, 20.8, 20.8, 20.7.

Penten-1-yl- $\beta$-D-2,3,4,6-tetra-O-acetyl-glucopyranoside (2f). 2 f was synthesized from $\beta$-D-glucose pentaacetate $(3.00 \mathrm{~g}$, $7.68 \mathrm{mmol})$, penten-1-yl alcohol $(0.99 \mathrm{~g}, 11.53 \mathrm{mmol})$, and boron trifluoride diethyl ether complex $(1.5 \mathrm{~mL}, 11.53 \mathrm{mmol})$. It was obtained as a white powder $(1.50 \mathrm{~g}, 47 \%) .{ }^{1} \mathrm{H}$ NMR $\left(400 \mathrm{MHz}, \mathrm{CDCl}_{3}\right): \delta 5.73(\mathrm{~m}, 1 \mathrm{H}), 5.16(\mathrm{~m}, 1 \mathrm{H}), 5.04(\mathrm{~m}$, $1 \mathrm{H}), 5.00-4.84(\mathrm{~m}, 3 \mathrm{H}), 4.45(\mathrm{~d}, J=8.1 \mathrm{~Hz}, 1 \mathrm{H}), 4.22(\mathrm{~m}$, $1 \mathrm{H}), 4.08(\mathrm{~m}, 1 \mathrm{H}), 3.83(\mathrm{~m}, 1 \mathrm{H}), 3.64(\mathrm{~m}, 1 \mathrm{H}), 3.45(\mathrm{~m}, 1 \mathrm{H})$, $2.20-1.83(\mathrm{~m}, 14 \mathrm{H}), 1.63(\mathrm{~m}, 2 \mathrm{H}) .{ }^{13} \mathrm{C}$ NMR $(100 \mathrm{MHz}$, $\left.\mathrm{CDCl}_{3}\right): \delta 170.7,170.3,169.4,169.3,137.8,115.1,100.9,72.9$, 71.8, 71.4, 69.3, 68.5, 62.0, 29.9, 28.6, 20.8, 20.7, 20.6, 20.6.

General Procedure for the Free Radical Addition of the Fluorinated Chains (Compounds $3 d-f$ ). To a solution of the corresponding alkyl- $\beta$-D-2,3,4,6-tetra- $O$-acetyl-glucopyranoside (2d-f) (1.0 equiv) in $\mathrm{CH}_{2} \mathrm{Cl}_{2}$, perfluoroallyliodide ( 1.5 equiv) and $1 \mathrm{M}$ triethyl borane in hexane ( 0.2 equiv) were added. The reaction mixture was purged with air and stirred at room temperature for about $1 \mathrm{~h}$. After completion of the reaction, a diluted solution of $\mathrm{Na}_{2} \mathrm{~S}_{2} \mathrm{O}_{3}$ was added and the aqueous layer was extracted with $\mathrm{CH}_{2} \mathrm{Cl}_{2}(3 \times)$. The organic layers were collected, dried over anhydrous $\mathrm{Na}_{2} \mathrm{SO}_{4}$, filtered, and concentrated under vacuum. The crude product was purified by flash chromatography (cyclohexane/AcOEt, 7:3 v/ v) to yield the desired compounds $3 \mathbf{d}-\mathbf{f}$.

$4^{\prime}, 4^{\prime}, 5^{\prime}, 5^{\prime}, 6^{\prime}, 6^{\prime}, 7^{\prime}, 7^{\prime}, 7^{\prime}$-Octafluoro-2' -iodo-heptyl- $\beta$-D2,3,4,6-tetra-O-acetyl-glucopyranoside (3d). $\mathbf{3 d}$ was synthe- 
sized from compound $2 \mathrm{~d}(1.13 \mathrm{~g}, 2.90 \mathrm{mmol})$, perfluorobutyl iodide $(1.51 \mathrm{~g}, 4.36 \mathrm{mmol})$, and $1 \mathrm{M}$ triethyl borane in hexane $(0.6 \mathrm{~mL}, 0.60 \mathrm{mmol})$. It was obtained as a white powder $(2.05$ $\mathrm{g}, 88 \%$ ) and as a mixture of two diastereoisomers (* indicates peaks from diastereotopic atoms). ${ }^{1} \mathrm{H}$ NMR (400 $\mathrm{MHz}$, $\left.\mathrm{CDCl}_{3}\right): \delta 5.21(\mathrm{~m}, 2 \mathrm{H}), 5.06(\mathrm{~m}, 4 \mathrm{H}), 4.58(\mathrm{~d}, J=7.7 \mathrm{~Hz}$, $1 \mathrm{H}), 4.57(\mathrm{~d}, J=8.0 \mathrm{~Hz}, 1 \mathrm{H}), 4.39(\mathrm{~m}, 1 \mathrm{H}), 4.34-4.17(\mathrm{~m}$, $3 \mathrm{H}), 4.12(\mathrm{~m}, 3 \mathrm{H}), 4.02(\mathrm{~m}, 1 \mathrm{H}), 3.80(\mathrm{~m}, 2 \mathrm{H}), 3.70(\mathrm{~m}, 2 \mathrm{H})$, $3.02(\mathrm{~m}, 2 \mathrm{H}), 2.64(\mathrm{~m}, 2 \mathrm{H}), 2.15-1.94(\mathrm{~m}, 24 \mathrm{H}) .{ }^{19} \mathrm{~F}$ NMR $\left(375 \mathrm{MHz}, \mathrm{CDCl}_{3}\right): \delta-81.0,-113.9,-124.6,-125.9 .{ }^{13} \mathrm{C}$ $\mathrm{NMR}\left(100 \mathrm{MHz}, \mathrm{CDCl}_{3}\right): \delta 170.6,170.2,169.4,169.2,101.1^{*}$ and $100.2^{*}\left(\underline{\mathrm{CH}}_{\text {anom. }}\right), 74.8^{*}$ and $73.6^{*}\left(\mathrm{OC}_{\mathrm{C}} \mathrm{CHI}\right), 72.6$, 72.0, 71.0, 68.3, 61.8, 37.5, 20.7, 20.6, 20.6, 13.6* and $13.1^{*}$ (대I).

$4^{\prime}, 4^{\prime}, 5^{\prime}, 5^{\prime}, 6^{\prime}, 6^{\prime}, 7^{\prime}, 7^{\prime}, 8^{\prime}, 8^{\prime}, 8^{\prime}$-Undecafluoro-2'-iodo-pentyl$\beta$-D-2,3,4,6-tetra-O-acetyl-glucopyranoside (3e). 3e was synthesized from compound $2 \mathrm{e}(0.78 \mathrm{~g}, 2.00 \mathrm{mmol})$, perfluoropentyl iodide $(1.07 \mathrm{~g}, 2.71 \mathrm{mmol})$, and $1 \mathrm{M}$ triethyl borane in hexane $(0.4 \mathrm{~mL}, 0.40 \mathrm{mmol})$. It was obtained as a white powder $(1.00 \mathrm{~g}, 67 \%)$ and as a mixture of two diastereoisomers (* indicates peaks from diastereotopic atoms). ${ }^{1} \mathrm{H} \mathrm{NMR}\left(400 \mathrm{MHz}, \mathrm{CDCl}_{3}\right): \delta 5.21(\mathrm{~m}, 2 \mathrm{H}) .5 .06$ $(\mathrm{m}, 4 \mathrm{H}), 4.58(\mathrm{~d}, J=8.0 \mathrm{~Hz}, 1 \mathrm{H}), 4.58(\mathrm{~d}, J=7.9 \mathrm{~Hz}, 1 \mathrm{H})$, $4.39(\mathrm{~m}, 1 \mathrm{H}), 4.34-4.18(\mathrm{~m}, 3 \mathrm{H}), 4.13(\mathrm{~m}, 3 \mathrm{H}), 4.03(\mathrm{~m}$, $1 \mathrm{H}), 3.80(\mathrm{~m}, 2 \mathrm{H}), 3.70(\mathrm{~m}, 2 \mathrm{H}), 3.02(\mathrm{~m}, 2 \mathrm{H}), 2.64(\mathrm{~m}, 2 \mathrm{H})$, 2.17-1.92 (m, 24H). ${ }^{19} \mathrm{~F}$ NMR (375 MHz, $\left.\mathrm{CDCl}_{3}\right): \delta-80.8$, -113.7, -122.6, -123.8, -126.2. ${ }^{13} \mathrm{C}$ NMR (100 MHz, $\left.\mathrm{CDCl}_{3}\right): \delta 170.7,170.3,169.5,169.4,101.2^{*}$ and $100.3^{*}$ $\left(\underline{\mathrm{CH}}_{\text {anom. }}\right), 74.9^{*}$ and $73.8^{*}\left(\mathrm{O}_{\mathrm{CH}} \mathrm{CHI}\right), 72.8,72.2,71.2$, $68.4,62.0^{*}$ and $61.9^{*}\left(\mathrm{CH}_{2} \mathrm{OAc}\right), 37.2,20.8,20.8,20.7,13.7^{*}$ and $13.3^{*}(\underline{\mathrm{CHI}})$.

$4^{\prime}, 4^{\prime}, 5^{\prime}, 5^{\prime}, 6^{\prime}, 6^{\prime}, 7^{\prime}, 7^{\prime}, 8^{\prime}, 8^{\prime}, 8^{\prime}$-Undecafluoro-4'-iodo-pentyl$\beta$-D-2,3,4,6-tetra-O-acetyl-glucopyranoside (3f). 3f was synthesized from compound $2 \mathrm{f}(1.50 \mathrm{~g}, 3.60 \mathrm{mmol})$, perfluoropropyliodide $(1.60 \mathrm{~g}, 5.4 \mathrm{mmol})$, and $1 \mathrm{M}$ triethyl borane in hexane $(0.7 \mathrm{~mL}, 0.72 \mathrm{mmol})$. It was obtained as a white powder (1.80 g, 70\%). ${ }^{1} \mathrm{H}$ NMR $\left(400 \mathrm{MHz}, \mathrm{CDCl}_{3}\right): \delta 5.20$ $(\mathrm{m}, 1 \mathrm{H}), 5.08(\mathrm{~m}, 1 \mathrm{H}), 4.98(\mathrm{~m}, 1 \mathrm{H}), 4.50(\mathrm{~d}, J=8.1 \mathrm{~Hz}$, $1 \mathrm{H}), 4.32(\mathrm{~m}, 1 \mathrm{H}), 4.25(\mathrm{~m}, 1 \mathrm{H}), 4.14(\mathrm{~m}, 1 \mathrm{H}), 3.91(\mathrm{~m}, 1 \mathrm{H})$, $3.69(\mathrm{~m}, 1 \mathrm{H}), 3.54(\mathrm{~m}, 1 \mathrm{H}), 2.83(\mathrm{~m}, 2 \mathrm{H}), 2.14-1.95(\mathrm{~m}$, $12 \mathrm{H}), 1.86(\mathrm{~m}, 3 \mathrm{H}), 1.70(\mathrm{~m}, 1 \mathrm{H}) .{ }^{19} \mathrm{~F}$ NMR $(375 \mathrm{MHz}$, $\left.\mathrm{CDCl}_{3}\right): \delta-80.3,-114.1,-127.9 .{ }^{13} \mathrm{C} \mathrm{NMR}(100 \mathrm{MHz}$, $\left.\mathrm{CDCl}_{3}\right): \delta 170.6,170.3,169.4,169.2,100.7,72.8,71.9,71.2$, 68.4, 61.9, 41.4, 36.9, 36.8, 29.8, 20.7, 20.6, 20.0.

General Procedure for the Elimination of the lodine Group (Compounds 4d-f). The corresponding compounds $\mathbf{3 d}-\mathbf{f}$ ( 1.0 equiv) were dissolved in $\mathrm{MeOH}$. To the resulting solution, $\mathrm{Pd} / \mathrm{C}$ (catalytic amount) and sodium acetate (3.2 equiv) were added. The reaction mixture was stirred overnight at room temperature and under a hydrogen atmosphere (6.5 bar). After completion of the reaction, the resulting mixture was filtered through a pad of Celite and concentrated under vacuum. The crude compound was dissolved in $\mathrm{CH}_{2} \mathrm{Cl}_{2}$ and washed with a diluted solution of $\mathrm{Na}_{2} \mathrm{~S}_{2} \mathrm{O}_{3}$. The aqueous layer was then extracted with $\mathrm{CH}_{2} \mathrm{Cl}_{2}(2 \times)$. The organic layers were collected, dried over anhydrous $\mathrm{Na}_{2} \mathrm{SO}_{4}$, filtered, and concentrated under vacuum to yield the desired compounds $\mathbf{4 d - f}$, which were used for the next step without any further purification.

$4^{\prime}, 4^{\prime}, 5^{\prime}, 5^{\prime}, 6^{\prime}, 6^{\prime}, 7^{\prime}, 7^{\prime}, 7^{\prime}$-Octafluoro-heptyl- $\beta$ - $D-2,3,4,6$ tetra-O-acetyl-glucopyranoside (4d). $4 \mathrm{~d}$ was synthesized from compound 3d (2.05 g, $2.79 \mathrm{mmol}), \mathrm{Pd} / \mathrm{C}(53 \mathrm{mg})$, and sodium acetate $(0.70 \mathrm{~g}, 8.93 \mathrm{mmol})$. It was obtained as a white powder $(1.50 \mathrm{~g}, 88 \%) .{ }^{1} \mathrm{H} \mathrm{NMR}\left(400 \mathrm{MHz}, \mathrm{CDCl}_{3}\right): \delta$ $5.19(\mathrm{~m}, 1 \mathrm{H}) .5 .07(\mathrm{~m}, 1 \mathrm{H}), 4.98(\mathrm{~m}, 1 \mathrm{H}), 4.50(\mathrm{~d}, J=8.0 \mathrm{~Hz}$, $1 \mathrm{H}), 4.24(\mathrm{~m}, 1 \mathrm{H}), 4.13(\mathrm{~m}, 1 \mathrm{H}), 3.93(\mathrm{~m}, 1 \mathrm{H}), 3.69(\mathrm{~m}, 1 \mathrm{H})$, $3.59(\mathrm{~m}, 1 \mathrm{H}), 2.26-1.95(\mathrm{~m}, 14 \mathrm{H}), 1.89(\mathrm{~m}, 2 \mathrm{H}) .{ }^{19} \mathrm{~F}$ NMR $\left(375 \mathrm{MHz}, \mathrm{CDCl}_{3}\right): \delta-81.1,-114.6,-124.5,-126.1 .{ }^{13} \mathrm{C}$ NMR $\left(100 \mathrm{MHz}_{\mathrm{CDCl}}\right): \delta 170.6,170.3,169.4,169.2,100.7$, 72.7, 71.9, 71.2, 68.4, 68.2, 61.9, 27.5, 20.7, 20.6, 20.6, 20.4.

$4^{\prime}, 4^{\prime}, 5^{\prime}, 5^{\prime}, 6^{\prime}, 6^{\prime}, 7^{\prime}, 7^{\prime}, 8^{\prime}, 8^{\prime}, 8^{\prime}$-Undecafluoro-pentyl- $\beta$ - $D$ 2,3,4,6-tetra-O-acetyl-glucopyranoside (4e). 4e was synthesized from compound $3 \mathrm{e}(1.00 \mathrm{~g}, 1.27 \mathrm{mmol}), \mathrm{Pd} / \mathrm{C}(50 \mathrm{mg})$, and sodium acetate $(0.33 \mathrm{~g}, 4.08 \mathrm{mmol})$. It was obtained as a white powder $(0.80 \mathrm{~g}, 70 \%) .{ }^{1} \mathrm{H} \mathrm{NMR}\left(400 \mathrm{MHz}, \mathrm{CDCl}_{3}\right): \delta$ $5.20(\mathrm{~m}, 1 \mathrm{H}), 5.08(\mathrm{~m}, 1 \mathrm{H}), 4.99(\mathrm{~m}, 1 \mathrm{H}), 4.50(\mathrm{~d}, J=8.0 \mathrm{~Hz}$, $1 \mathrm{H}), 4.24(\mathrm{~m}, 1 \mathrm{H}), 4.13(\mathrm{~m}, 1 \mathrm{H}), 3.94(\mathrm{~m}, 1 \mathrm{H}), 3.69(\mathrm{~m}, 1 \mathrm{H})$, $3.59(\mathrm{~m}, 1 \mathrm{H}), 2.24-1.97(\mathrm{~m}, 14 \mathrm{H}), 1.88(\mathrm{~m}, 2 \mathrm{H}) .{ }^{19} \mathrm{~F}$ NMR $\left(375 \mathrm{MHz}, \mathrm{CDCl}_{3}\right): \delta-81.8,-114.4,-122.7,-123.7$, -126.3. ${ }^{13} \mathrm{C} \mathrm{NMR}\left(100 \mathrm{MHz}, \mathrm{CDCl}_{3}\right): \delta 170.8,170.4$, $169.5,169.4,100.8,72.9,72.0,71.3,68.5,68.4,62.0,27.6,20.9$, $20.8,20.7,20.6$.

$6^{\prime}, 6^{\prime}, 7^{\prime}, 7^{\prime}, 8^{\prime}, 8^{\prime}, 8^{\prime}$-Heptafluoro-octyl- $\beta$-D-2,3,4,6-tetra-Oacetyl-glucopyranoside (4f). 4f was synthesized from compound $3 \mathrm{f}(0.70 \mathrm{~g}, 0.98 \mathrm{mmol}), \mathrm{Pd} / \mathrm{C}(50 \mathrm{mg})$, and sodium acetate $(0.25 \mathrm{~g}, 3.14 \mathrm{mmol})$. It was obtained as a white powder $(0.40 \mathrm{~g}, 69 \%) .{ }^{1} \mathrm{H} \mathrm{NMR}\left(400 \mathrm{MHz}, \mathrm{CDCl}_{3}\right): \delta 5.20$ $(\mathrm{m}, 1 \mathrm{H}), 5.08(\mathrm{~m}, 1 \mathrm{H}), 4.98(\mathrm{~m}, 1 \mathrm{H}), 4.49(\mathrm{~d}, J=8.1 \mathrm{~Hz}$, $1 \mathrm{H}), 4.26(\mathrm{~m}, 1 \mathrm{H}), 4.13(\mathrm{~m}, 1 \mathrm{H}), 3.88(\mathrm{~m}, 1 \mathrm{H}), 3.69(\mathrm{~m}, 1 \mathrm{H})$, $3.49(\mathrm{~m}, 1 \mathrm{H}), 2.11-1.97(\mathrm{~m}, 14 \mathrm{H}), 1.61(\mathrm{~m}, 4 \mathrm{H}), 1.43(\mathrm{~m}$, $2 \mathrm{H}) .{ }^{19} \mathrm{~F} \mathrm{NMR}\left(375 \mathrm{MHz}, \mathrm{CDCl}_{3}\right): \delta-80.6,-115.4,-127.8$. ${ }^{13} \mathrm{C}$ NMR (100 MHz, $\left.\mathrm{CDCl}_{3}\right): \delta 170.8,170.4,169.5,169.4$, 100.9, 73.0, 71.9, 71.5, 69.6, 68.5, 62.1, 30.6, 29.2, 25.5, 20.8, 20.7, 19.9 .

General Procedure for the Deprotection of Peracetylated Glucose (Compounds $3 a-c$ and 5d-f). The corresponding compounds $\mathbf{2 a}-\mathbf{c}$ and $\mathbf{4 d}-\mathbf{f}$ were dissolved in $\mathrm{MeOH}$ and then a catalytic amount of sodium methoxide was added. The reaction mixture was stirred overnight at room temperature. The solution was neutralized by adding IRC-50, filtered, and concentrated under vacuum. The crude compound was purified by flash chromatography on a silica gel $(\mathrm{DCM} / \mathrm{MeOH}, 85: 15 \mathrm{v} / \mathrm{v})$ to yield the desired compounds $\mathbf{2 a}-\mathbf{c}$ and $\mathbf{4 d}-\mathbf{f}$.

$4^{\prime}, 4^{\prime}, 5^{\prime}, 5^{\prime}, 6^{\prime}, 6^{\prime}, 6^{\prime}$-Heptafluorohexyl- $\beta$-D-glucopyranoside (3a). 3a was synthesized from compound 2a (0.90 g, 1.61 $\mathrm{mmol}$ ) and sodium methoxide $(43 \mathrm{mg}, 0.80 \mathrm{mmol})$. It was obtained as a white powder (0.57 g, 92\%). ${ }^{1} \mathrm{H}$ NMR (400 $\left.\mathrm{MHz}, \mathrm{CD}_{3} \mathrm{OD}\right): \delta 4.26(\mathrm{~d}, J=7.8 \mathrm{~Hz}, 1 \mathrm{H}), 3.99(\mathrm{~m}, 1 \mathrm{H}), 3.87$ $(\mathrm{m}, 1 \mathrm{H}), 3.67(\mathrm{~m}, 2 \mathrm{H}), 3.38-3.25(\mathrm{~m}, 3 \mathrm{H}), 3.18(\mathrm{~m}, 1 \mathrm{H})$, $2.32(\mathrm{~m}, 2 \mathrm{H}), 1.91(\mathrm{~m}, 2 \mathrm{H}) .{ }^{19} \mathrm{~F}$ NMR (375 MHz, $\left.\mathrm{CD}_{3} \mathrm{OD}\right): \delta$ -82.2, -116.5, -129.04. ${ }^{13} \mathrm{C}$ NMR $\left(100 \mathrm{MHz}, \mathrm{CD}_{3} \mathrm{OD}\right): \delta$ 104.3, 78.0, 77.9, 75.0, 71.7, 69.1, 62.8, 28.6, 21.9. HRMS (ESI-TOF) $m / z:[\mathrm{M}+\mathrm{H}]^{+}$calcd for $\mathrm{C}_{12} \mathrm{H}_{17} \mathrm{~F}_{7} \mathrm{O}_{6}, 391.0992$; found, 391.0993 .

$3^{\prime}, 3^{\prime}, 4^{\prime}, 4^{\prime}, 5^{\prime}, 5^{\prime}, 6^{\prime}, 6^{\prime}, 6^{\prime}$-Nonafluorohexyl- $\beta$-D-glucopyranoside (3b). $\mathbf{3 b}$ was synthesized from compound $\mathbf{2 b}(0.90 \mathrm{~g}, 1.51$ $\mathrm{mmol}$ ) and sodium methoxide $(40 \mathrm{mg}, 0.75 \mathrm{mmol})$. It was obtained as a white powder (0.60 g, 93\%). ${ }^{1} \mathrm{H}$ NMR (400 $\left.\mathrm{MHz}, \mathrm{CD}_{3} \mathrm{OD}\right): \delta 4.30$ (d, $\left.J=7.8 \mathrm{~Hz}, 1 \mathrm{H}\right), 4.19(\mathrm{~m}, 1 \mathrm{H}), 3.88$ $(\mathrm{m}, 2 \mathrm{H}), 3.67(\mathrm{~m}, 1 \mathrm{H}), 3.39-3.26(\mathrm{~m}, 3 \mathrm{H}), 3.18(\mathrm{~m}, 1 \mathrm{H})$, $2.57(\mathrm{~m}, 2 \mathrm{H}) .{ }^{19} \mathrm{~F}$ NMR $\left(375 \mathrm{MHz}, \mathrm{CD}_{3} \mathrm{OD}\right): \delta-82.7$, $-114.7,-125.7,-127.2 .{ }^{13} \mathrm{C}$ NMR $\left(100 \mathrm{MHz}, \mathrm{CD}_{3} \mathrm{OD}\right): \delta$ 104.6, 78.0, 78.0, 75.0, 71.6, 62.7, 62.6, 32.5. HRMS (ESITOF) $m / z:[\mathrm{M}+\mathrm{H}]^{+}$calcd for $\mathrm{C}_{12} \mathrm{H}_{15} \mathrm{~F}_{9} \mathrm{O}_{6}, 427.0803$; found, 427.0794 . 
$3^{\prime}, 3^{\prime}, 4^{\prime}, 4^{\prime}, 5^{\prime}, 5^{\prime}, 6^{\prime}, 6^{\prime}, 7^{\prime}, 7^{\prime}, 8^{\prime}, 8^{\prime}, 8^{\prime}$-Tridecafluorooctan- $\beta-D$ glucopyranoside (3c). $3 \mathrm{c}$ was synthesized from compound $2 \mathrm{c}$ $(1.40 \mathrm{~g}, 2.02 \mathrm{mmol})$ and sodium methoxide $(55 \mathrm{mg}, 0.50$ $\mathrm{mmol})$. It was obtained as a white powder $(0.93 \mathrm{~g}, 93 \%) .{ }^{1} \mathrm{H}$ NMR (400 MHz, $\left.\mathrm{CD}_{3} \mathrm{OD}\right): \delta 4.30(\mathrm{~d}, J=7.8 \mathrm{~Hz}, 1 \mathrm{H}), 4.19$ $(\mathrm{m}, 1 \mathrm{H}), 3.88(\mathrm{~m}, 2 \mathrm{H}), 3.67(\mathrm{~m}, 1 \mathrm{H}), 3.39-3.27(\mathrm{~m}, 3 \mathrm{H})$, $3.18(\mathrm{~m}, 1 \mathrm{H}), 2.58(\mathrm{~m}, 2 \mathrm{H}) .{ }^{19} \mathrm{~F} \mathrm{NMR}\left(375 \mathrm{MHz}, \mathrm{CD}_{3} \mathrm{OD}\right): \delta$ $-82.4,-114.5,-122.9,-123.9,-124.7,-127.3 .{ }^{13} \mathrm{C} \mathrm{NMR}$ (100 MHz, $\left.\mathrm{CD}_{3} \mathrm{OD}\right): \delta 104.6,78.0,78.0,75.0,71.6,62.7,62.6$, 32.6. HRMS (ESI-TOF) $m / z:[\mathrm{M}+\mathrm{H}]^{+}$calcd for $\mathrm{C}_{14} \mathrm{H}_{15} \mathrm{~F}_{13} \mathrm{O}_{6}, 527.0739$; found, 527.0734.

$4^{\prime}, 4^{\prime}, 5^{\prime}, 5^{\prime}, 6^{\prime}, 6^{\prime}, 7^{\prime}, 7^{\prime}, 7^{\prime}$-Octafluoroheptyl- $\beta$-D-glucopyranoside (5d). 5d was synthesized from compound $4 \mathbf{d}(1.50 \mathrm{~g}$, $2.47 \mathrm{mmol}$ ) and sodium methoxide (50 $\mathrm{mg}, 0.98 \mathrm{mmol})$. It was obtained as a white powder $(0.97 \mathrm{~g}, 90 \%) .{ }^{1} \mathrm{H}$ NMR (400 $\left.\mathrm{MHz}, \mathrm{CD}_{3} \mathrm{OD}\right): \delta 4.27$ (d, $\left.J=7.8 \mathrm{~Hz}, 1 \mathrm{H}\right), 3.99(\mathrm{~m}, 1 \mathrm{H}), 3.87$ $(\mathrm{m}, 1 \mathrm{H}), 3.66(\mathrm{~m}, 2 \mathrm{H}), 3.40-3.25(\mathrm{~m}, 3 \mathrm{H}), 3.18(\mathrm{~m}, 1 \mathrm{H})$, $2.34(\mathrm{~m}, 2 \mathrm{H}), 1.91(\mathrm{~m}, 2 \mathrm{H}) .{ }^{19} \mathrm{~F} \mathrm{NMR}\left(375 \mathrm{MHz}, \mathrm{CD}_{3} \mathrm{OD}\right): \delta$ -82.7, -115.7, -125.5, -127.3. ${ }^{13} \mathrm{C}$ NMR (100 MHz, $\left.\mathrm{CD}_{3} \mathrm{OD}\right): \delta 104.3,78.1,78.0,75.0,71.7,69.1,62.8,28.8$, 21.9. HRMS (ESI-TOF) $m / z$ : $[\mathrm{M}+\mathrm{H}]^{+}$calcd for $\mathrm{C}_{13} \mathrm{H}_{17} \mathrm{~F}_{9} \mathrm{O}_{6}$, 441.0960; found, 441.0946 .

$4^{\prime}, 4^{\prime}, 5^{\prime}, 5^{\prime}, 6^{\prime}, 6^{\prime}, 7^{\prime}, 7^{\prime}, 8^{\prime}, 8^{\prime}, 8^{\prime}$-Undecafluorooctyl- $\beta$-D-glucopyranoside (5e). $5 \mathbf{e}$ was synthesized from compound $4 \mathbf{e}(0.80$ g, $1.21 \mathrm{mmol}$ ) and sodium methoxide $(33 \mathrm{mg}, 0.61 \mathrm{mmol})$. It was obtained as a white powder $(0.57 \mathrm{~g}, 92 \%) .{ }^{1} \mathrm{H}$ NMR (400 $\left.\mathrm{MHz}, \mathrm{CD}_{3} \mathrm{OD}\right): \delta 4.28(\mathrm{~d}, J=7.8 \mathrm{~Hz}, 1 \mathrm{H}), 4.00(\mathrm{~m}, 1 \mathrm{H}), 3.88$ $(\mathrm{m}, 1 \mathrm{H}), 3.68(\mathrm{~m}, 2 \mathrm{H}), 3.41-3.24(\mathrm{~m}, 3 \mathrm{H}), 3.20(\mathrm{~m}, 1 \mathrm{H})$, $2.36(\mathrm{~m}, 2 \mathrm{H}), 1.93(\mathrm{~m}, 2 \mathrm{H}) .{ }^{19} \mathrm{~F} \mathrm{NMR}\left(375 \mathrm{MHz}, \mathrm{CD}_{3} \mathrm{OD}\right): \delta$ $-82.5,-115.5,-123.8,-124.7,-127.5 .{ }^{13} \mathrm{C}$ NMR $(100 \mathrm{MHz}$, $\left.\mathrm{CD}_{3} \mathrm{OD}\right): \delta$ 104.3. 78.1, 78.0, 75.0, 71.7, 69.1, 62.8, 28.9, 21.9. HRMS (ESI-TOF) $m / z$ : $[\mathrm{M}+\mathrm{H}]^{+}$calcd for $\mathrm{C}_{14} \mathrm{H}_{17} \mathrm{~F}_{11} \mathrm{O}_{6}$, 491.0928; found, 491.0919.

$6^{\prime}, 6^{\prime}, 7^{\prime}, 7^{\prime}, 8^{\prime}, 8^{\prime}, 8^{\prime}$-Heptafluorooctyl- $\beta$-D-glucopyranoside (5f). 5f was synthesized from compound 4 ff $(0.40 \mathrm{~g}, 0.68$ $\mathrm{mmol}$ ) and sodium methoxide $(20 \mathrm{mg}, 0.35 \mathrm{mmol})$. It was obtained as a white powder $(0.24 \mathrm{~g}, 84 \%) .{ }^{1} \mathrm{H}$ NMR (400 $\left.\mathrm{MHz}, \mathrm{CD}_{3} \mathrm{OD}\right): \delta 4.25(\mathrm{~d}, J=7.8 \mathrm{~Hz}, 1 \mathrm{H}), 3.92(\mathrm{~m}, 1 \mathrm{H}), 3.86$ $(\mathrm{m}, 1 \mathrm{H}), 3.67(\mathrm{~m}, 1 \mathrm{H}), 3.57(\mathrm{~m}, 1 \mathrm{H}), 3.38-3.22(\mathrm{~m}, 3 \mathrm{H})$, $3.17(\mathrm{~m}, 1 \mathrm{H}), 2.15(\mathrm{~m}, 2 \mathrm{H}), 1.64(\mathrm{~m}, 4 \mathrm{H}), 1.52(\mathrm{~m}, 2 \mathrm{H}) .{ }^{19} \mathrm{~F}$ NMR $\left(375 \mathrm{MHz}, \mathrm{CD}_{3} \mathrm{OD}\right): \delta-82.2,-116.4,-129.1 .{ }^{13} \mathrm{C}$ NMR (100 MHz, CD 3 OD): $\delta 104.4,78.1,77.9,75.1,71.7$, $70.4,62.8,31.5,30.4,26.6,21.1$. HRMS (ESI-TOF) $\mathrm{m} / z$ : $[\mathrm{M}$ $+\mathrm{H}]^{+}$calcd for $\mathrm{C}_{14} \mathrm{H}_{21} \mathrm{~F}_{7} \mathrm{O}_{6}, 419.1305$; found, 419.1301 .

Determination of Water Solubility. The turbidity of the aqueous solution of compounds was measured by a CrystalEYES system (manufactured by HEL Limited). This system includes a turbidity probe, a temperature probe, and a recorder. For each compound, a turbid solution, at a concentration around three times its limit of solubility, was prepared. The stock solution was maintained at $25{ }^{\circ} \mathrm{C}$ using a thermostat (Ministat 125 series, Huber) under stirring at 350 $\mathrm{rpm}$. The turbidity and temperature probes were immersed in the stock solution and the turbidity was measured after $10 \mathrm{~min}$ of stirring. The stock solution was diluted by successive addition of water. After each addition of water, the stirring was continued for $10 \mathrm{~min}$ and the turbidity was recorded.

Surface Tension Measurements. The surface tension of the aqueous solution of compounds was determined using a K100 tensiometer (KRUSS, Hamburg, Germany). The Wilhelmy plate technique was employed. Surfactant solutions around the limit of solubility were prepared $24 \mathrm{~h}$ prior to measurements, and $20 \mathrm{~mL}$ of the solution was transferred to a
$50 \mathrm{~mL}$ vessel supplied with a stirring bar. Surface tensions were determined by the automatic dilution of the stock solutions using a Metrohm 700 Dosino. In a typical experiment, 20-30 concentration steps were used with $\sim 5-10$ min between each concentration step. All measurements were performed at 25.0 $\pm 0.5{ }^{\circ} \mathrm{C}$. Sets of measurements to obtain equilibrium surface tension were taken until the change in surface tension was less than $0.05 \mathrm{mN} / \mathrm{m}$.

${ }^{19} \mathrm{~F}$ NMR for CMC Determination. Seven samples at different concentrations were prepared from a stock solution of each surfactant $\left(8.7 \mathrm{~g} / \mathrm{L}\right.$ for $\mathrm{F}_{4} \mathrm{H}_{2}-\beta$-Glu and $7.6 \mathrm{~g} / \mathrm{L}$ for $\mathrm{F}_{3} \mathrm{H}_{5^{-}}$ $\beta$-Glu) and were dissolved in $500 \mu \mathrm{L}$ of a $\mathrm{D}_{2} \mathrm{O} / \mathrm{H}_{2} \mathrm{O}(1: 9, \mathrm{v} / \mathrm{v})$ mixture. $\mathrm{CF}_{3} \mathrm{COONa}(-73.53 \mathrm{ppm})$ was used as the internal reference and $20 \mu \mathrm{L}$ of a solution at $1 \mathrm{~g} / \mathrm{L}$ was added to each of the samples. ${ }^{19} \mathrm{~F}$ NMR spectra were recorded on a Bruker AC400 at $376.50 \mathrm{MHz}$ at $25{ }^{\circ} \mathrm{C}$. The observed chemical shifts $\left(\delta_{\text {obs }}\right)$ of the terminal $\mathrm{CF}_{3}$ group of the derivative were plotted as a function of the concentration below and above the CMC. Below the CMC, $\delta_{\text {obs }}$ corresponds to the chemical shift of the monomer $\left(\delta_{\text {mon }}\right)$, whereas above the CMC, $\delta_{\text {obs }}$ is the weighted average of the chemical shifts of the monomer and the formed micelle, assuming that the exchange between the bulk solution and the micelle is fast on the NMR time scale. If the monomer concentration is constant above the CMC, the observed chemical shift can be determined using eq 1

$$
\delta_{\text {obs }}=\delta_{\text {mic }}-\left(\frac{\mathrm{CMC}}{\mathrm{C}}\right)\left(\delta_{\text {mic }}-\delta_{\text {mon }}\right)
$$

Hydrophilic-Lipophilic Balance Determination. HLB values according to Griffin's method ${ }^{29}$ were determined using eq 2

$$
\mathrm{HLBG}=20 \times \frac{M_{\mathrm{h}}}{M}
$$

where $M_{\mathrm{h}}$ is the molecular weight of the hydrophilic part (here $179.1 \mathrm{~g} / \mathrm{mol}$ ) and $M$ is the molecular weight of the whole molecule. HLB values according to Davies' method ${ }^{30}$ were determined using eq 3

$$
\begin{aligned}
\text { HLBD }= & 7+\sum \text { hydrophilic group numbers } \\
& +\sum \text { hydrophobic group numbers }
\end{aligned}
$$

For the glucose polar head group, we assigned a value of 1.9 for the primary $\mathrm{OH}$ group $(1 \times 1.9)$ and a value of 0.5 for the three secondary $\mathrm{OH}$ groups $(3 \times 0.5)$. A value of 1.3 was assigned for each ether group $(2 \times 1.3)$. For the alkyl chains, the group numbers were -0.475 per each $\mathrm{CH}_{2}$ or $\mathrm{CH}_{3}$ group and -0.870 per each $\mathrm{CF}_{2}$ or $\mathrm{CF}_{3}$ group. ${ }^{32}$ The first methylene group of the chain connected to the polar head group was excluded from the calculation.

Crystallization of AcrB. AcrB was expressed and purified as described in ref 34. Purified AcrB was concentrated to more than $15 \mathrm{mg} / \mathrm{mL}$ (Amicon, 50kDa cutoff). The final buffer contains $10 \mathrm{mM}$ Na-HEPES at $\mathrm{pH} 7$ and $0.02 \%$ DDM (Anatrace, Anagrade). First crystallization was done on the PSB crystallization platform (High Throughput Crystallization Laboratory (HTX Lab) of the EMBL Grenoble, ${ }^{35}$ ) using the MemGold kit (Molecular Dimensions) diluted 50\% (v/v) with water to identify initial crystallization conditions. $\mathrm{F}_{3} \mathrm{H}_{5}-\beta$-Glu was dissolved in the same buffer as AcrB at a concentration of up to $0.5 \%$. Prior to crystallization, various amounts of $\mathrm{F}_{3} \mathrm{H}_{5}-\beta$ Glu were added to the protein solution to obtain final 
Table 2. Crystallization Conditions Selected from a 96-Conditions Screen ${ }^{a}$

\begin{tabular}{|c|c|c|c|c|}
\hline conditions & buffer & precipitant & salt & effect of $\mathrm{F}_{3} \mathrm{H}_{5}-\beta$-Glu \\
\hline 1 & 25 mM bicine, $\mathrm{pH} 9.0$ & $16.5 \%(\mathrm{v} / \mathrm{v})$ PEG 300 & $50 \mathrm{mM} \mathrm{NaCl}$ & strong improvement \\
\hline 2 & $25 \mathrm{mM} \mathrm{Na}$ citrate, $\mathrm{pH} 4.5$ & $11 \%(\mathrm{v} / \mathrm{v})$ PEG400 & $35 \mathrm{mM} \mathrm{NaCl}$ & no effect \\
\hline 3 & 50 mM glycine, pH 9.3 & $15 \%(v / v)$ PEG400 & $50 \mathrm{mM} \mathrm{LiSO}_{4}$ & no effect \\
\hline 4 & $50 \mathrm{mM}$ tris, $\mathrm{pH} 8.0$ & $17.5 \%(\mathrm{v} / \mathrm{v})$ PEG400 & $110 \mathrm{mM} \mathrm{Na}$ citrate & strong improvement \\
\hline 5 & $40 \mathrm{mM} \mathrm{NaPO}_{4}, \mathrm{pH} 6.2$ & $9 \%(\mathrm{w} / \mathrm{v})$ PEG2000 & $10 \mathrm{mM} \mathrm{Na}$ citrate & moderate improvement \\
\hline 6 & no buffer & $11 \%(\mathrm{w} / \mathrm{v})$ PEG6000 & $25 \mathrm{mM} \mathrm{Li}$ citrate, $50 \mathrm{mM} \mathrm{NaHPO}$, $75 \mathrm{mM} \mathrm{K}$ citrate & no effect \\
\hline
\end{tabular}

${ }^{a_{T}}$ The improvement of crystallization in the presence of $\mathrm{F}_{3} \mathrm{H}_{5}-\beta$-Glu was observed in conditions 1 , 4, and 5 .

concentrations of $0,0.002,0.02$, and $0.04 \%$ of $\mathrm{F}_{3} \mathrm{H}_{5}-\beta$-Glu, while keeping the same AcrB and DDM concentrations, respectively, $11.6 \mathrm{mg} / \mathrm{mL}$ and $0.02 \%$, in all samples. Handmade drops made of $1.2 \mu \mathrm{L}$ of protein solution and $1.2 \mu \mathrm{L}$ of the reservoir were suspended over $800 \mu \mathrm{L}$ of reservoirs in 24well plates. Crystals appear within a few days to 1 week. Selected crystallization conditions are shown in Table 2.

\section{ASSOCIATED CONTENT}

\section{SI Supporting Information}

The Supporting Information is available free of charge at https://pubs.acs.org/doi/10.1021/acsomega.1c02581.

${ }^{1} \mathrm{H},{ }^{19} \mathrm{~F}$, and ${ }^{13} \mathrm{C}$ NMR spectra and mass spectrometry data of compounds $3 \mathbf{a}-\mathbf{c}$ and $\mathbf{5} \mathbf{d}-\mathbf{f}$ (PDF)

\section{AUTHOR INFORMATION}

\section{Corresponding Author}

Grégory Durand - Institut des Biomolécules Max Mousseron (UMR 5247 UM-CNRS-ENSCM) \& Avignon University,

Equipe Chimie Bioorganique et Systèmes amphiphiles, 84916 Avignon, France; (1) orcid.org/0000-0001-6680-2821; Phone: +33490144445; Email: gregory.durand@univavignon.fr

\section{Authors}

Moheddine Wehbie - Institut des Biomolécules Max Mousseron (UMR 5247 UM-CNRS-ENSCM) \& Avignon University, Equipe Chimie Bioorganique et Systèmes amphiphiles, 84916 Avignon, France

Ilham Bouchemal - Univ. Grenoble Alpes, CNRS, CEA, IBS, F-38000 Grenoble, France

Anaïs Deletraz - Institut des Biomolécules Max Mousseron (UMR 5247 UM-CNRS-ENSCM) \& Avignon University, Equipe Chimie Bioorganique et Systèmes amphiphiles, 84916 Avignon, France

Eva Pebay-Peyroula - Univ. Grenoble Alpes, CNRS, CEA, IBS, F-38000 Grenoble, France

Cécile Breyton - Univ. Grenoble Alpes, CNRS, CEA, IBS, F38000 Grenoble, France

Christine Ebel - Univ. Grenoble Alpes, CNRS, CEA, IBS, F38000 Grenoble, France

Complete contact information is available at:

https://pubs.acs.org/10.1021/acsomega.1c02581

\section{Notes}

The authors declare no competing financial interest.

\section{ACKNOWLEDGMENTS}

This work was supported by the Agence Nationale de la Recherche (ANR) through grant no. ANR-16-CE92-0001. The authors acknowledge the financial support of the European
Regional Development Fund, the French Government, the "Région Provence Alpes Côte d'Azur", the "Département de Vaucluse", and the "Communauté d'agglomération Grand Avignon" for access to the NMR platform (CPER 3A). This work used the platforms of the Grenoble Instruct-ERIC center (ISBG; UAR 3518 CNRS-CEA-UGA-EMBL) within the Grenoble Partnership for Structural Biology (PSB), supported by FRISBI (ANR-10-INBS-05-02) and GRAL, financed within the University Grenoble Alpes graduate school (Ecoles Universitaires de Recherche) CBH-EUR-GS (ANR-17EURE-0003). I.B. acknowledges integration into the Interdisciplinary Research Institute of Grenoble (IRIG, CEA). The authors thank Florine Dupeux for access to the HTX lab facility at EMBL and the PSB and Delphine Baud for her advice on AcrB production.

\section{REFERENCES}

(1) Breibeck, J.; Rompel, A. Successful amphiphiles as the key to crystallization of membrane proteins: Bridging theory and practice. Biochim. Biophys. Acta, Gen. Subj. 2019, 1863, 437-455.

(2) Denisov, I. G.; Sligar, S. G. Nanodiscs in membrane biochemistry and biophysics. Chem. Rev. 2017, 117, 4669-4713.

(3) Zabara, A.; Meikle, T. G.; Trenker, R.; Yao, S.; Newman, J.; Peat, T. S.; Separovic, F.; Conn, C. E.; Call, M. J.; Call, M. E.; Landau, E. M.; Drummond, C. J. Lipidic cubic phase-induced membrane protein crystallization: Interplay between lipid molecular structure, mesophase structure and properties, and crystallogenesis. Cryst. Growth Des. 2017, 17, 5667-5674.

(4) Allen, J. Recent innovations in membrane-protein structural biology. F1000Research 2019, 8, No. 211.

(5) Loll, P. J. Membrane proteins, detergents and crystals: what is the state of the art? Acta Crystallogr., Sect. F: Struct. Biol. Commun. 2014, 70, 1576-1583.

(6) Stetsenko, A.; Guskov, A. An overview of the top ten detergents used for membrane protein crystallization. Crystals 2017, 7, No. 197.

(7) Parker, J. L.; Newstead, S. Current trends in $\alpha$-helical membrane protein crystallization: an update. Protein Sci. 2012, 21, 1358-1365.

(8) Deisenhofer, J.; Epp, O.; Miki, K.; Huber, R.; Michel, H. Structure of the protein subunits in the photosynthetic reaction centre of Rhodopseudomonas viridis at $3 \AA$ resolution. Nature 1985, 318, 618-624.

(9) Durand, G.; Abla, M.; Ebel, C.; Breyton, C. New amphiphiles to handle membrane proteins: "Ménage à trois" between chemistry, physical chemistry, and biochemistry. In Membrane Proteins Production for Structural Analysis; Mus-Veteau, I., Ed.; Springer: New York, 2014; pp 205-251.

(10) Frotscher, E.; Danielczak, B.; Vargas, C.; Meister, A.; Durand, G.; Keller, S. A fluorinated detergent for membrane-protein applications. Angew. Chem., Int. Ed. 2015, 54, 5069-5073.

(11) Boussambe, G. N. M.; Guillet, P.; Mahler, F.; Marconnet, A.; Vargas, C.; Cornut, D.; Soulié, M.; Ebel, C.; Roy, A. L.; Jawhari, A.; Bonneté, F.; Keller, S.; Durand, G. Fluorinated diglucose detergents for membrane-protein extraction. Methods 2018, 147, 84-94.

(12) Faugier, C.; Igonet, S.; Cornut, D.; Besson, R.; Durand, G.; Jawhari, A. Lactobionamide-based fluorinated detergent for functional 
and structural stabilization of membrane proteins. Methods 2020, 180, $19-26$.

(13) Wehbie, M.; Onyia, K. K.; Mahler, F.; Le Roy, A.; Deletraz, A.; Bouchemal, I.; Vargas, C.; Babalola, J. O.; Breyton, C.; Ebel, C.; Keller, S.; Durand, G. Maltose-based fluorinated surfactants for membrane-protein extraction and stabilization. Langmuir 2021, 37, 2111-2122.

(14) Takahashi, H.; Yoshino, M.; Morita, K.; Takagi, T.; Yokoyama, Y.; Kikukawa, T.; Amii, H.; Kanamori, T.; Sonoyama, M. Stability of the two-dimensional lattice of bacteriorhodopsin reconstituted in partially fluorinated phosphatidylcholine bilayers. Biochim. Biophys. Acta, Biomembr. 2019, 1861, 631-642.

(15) Baba, T.; Takagi, T.; Sumaru, K.; Kanamori, T.; Dewa, T.; Nango, M. Membrane properties of ether-type phosphatidylcholine bearing partially fluorinated C18-monoacetylenic chains and their applicability to membrane protein reconstitution matrices. Colloids Surf., B 2021, 198, No. 111459.

(16) Nordstierna, L.; Furó, I.; Stilbs, P. Mixed micelles of fluorinated and hydrogenated surfactants. J. Am. Chem. Soc. 2006, 128, 67046712.

(17) Long, P.; Hao, J. Phase behavior and self-assembly aggregation of hydrocarbon and fluorocarbon surfactant mixtures in aqueous solution. Adv. Colloid Interface Sci. 2012, 171-172, 66-76.

(18) Zhang, P.; Wang, J.; Shi, Y. Structure and mechanism of the S component of a bacterial ECF transporter. Nature 2010, 468, 717720.

(19) Efremov, R. G.; Baradaran, R.; Sazanov, L. A. The architecture of respiratory complex I. Nature 2010, 465, 441-445.

(20) Baradaran, R.; Berrisford, J. M.; Minhas, G. S.; Sazanov, L. A. Crystal structure of the entire respiratory complex I. Nature 2013, 494, 443-448.

(21) Luo, F.; Shinzawa-Itoh, K.; Hagimoto, K.; Shimada, A.; Shimada, S.; Yamashita, E.; Yoshikawa, S.; Tsukihara, T. Structure of bovine cytochrome $\mathrm{c}$ oxidase crystallized at a neutral $\mathrm{pH}$ using a fluorinated detergent. Acta Crystallogr., Sect. F: Struct. Biol. Commun. 2017, 73, 416-422.

(22) Shimada, S.; Shinzawa-Itoh, K.; Baba, J.; Aoe, S.; Shimada, A.; Yamashita, E.; Kang, J.; Tateno, M.; Yoshikawa, S.; Tsukihara, T. Complex structure of cytochrome c-cytochrome $\mathrm{c}$ oxidase reveals a novel protein-protein interaction mode. EMBO J. 2017, 36, 291-300.

(23) Yoon, J. Y.; Kim, J.; An, D. R.; Lee, S. J.; Kim, H. S.; Im, H. N.; Yoon, H. J.; Kim, J. Y.; Kim, S. J.; Han, B. W.; Suh, S. W. Structural and functional characterization of HP0377, a thioredoxin-fold protein from Helicobacter pylori. Acta Crystallogr., Sect. D: Biol. Crystallogr. 2013, 69, 735-746.

(24) Sobolev, V.; Edelman, M.; Dym, O.; Unger, T.; Albeck, S.; Kirma, M.; Galili, G. Structure of ALD1, a plant-specific homologue of the universal diaminopimelate aminotransferase enzyme of lysine biosynthesis. Acta Crystallogr., Sect. F: Struct. Biol. Cryst. Commun. 2013, 69, 84-89.

(25) Monde, K.; Miura, N.; Hashimoto, M.; Taniguchi, T.; Inabe, T. Conformational analysis of chiral helical perfluoroalkyl chains by VCD. J. Am. Chem. Soc. 2006, 128, 6000-6001.

(26) Takeyama, Y.; Ichinose, Y.; Oshima, K.; Utimoto, K. Triethylborane-induced stereoselective radical addition of perfluoroalkyl iodides to acetylenes. Tetrahedron Lett. 1989, 30, 3159-3162.

(27) Kozo, S.; Tokio, Y.; Ryohei, H. The surface tension and the critical micelle concentration in aqueous solution of $\beta$-D-alkyl glucosides and their mixtures. Bull. Chem. Soc. Jpn. 1961, 34, 237241.

(28) Griffin, W. C. Classification of surface-active agents by "HLB". J. Soc. Cosmet. Chem. 1949, 1, 311-326.

(29) Griffin, W. C. Calculation of HLB values of non-ionic surfactants. J. Soc. Cosmet. Chem. 1954, 5, 249-256.

(30) Davies, J. T. In A quantitative kinetic theory of emulsion type, I. Physical chemistry of the emulsifying agent, Proceedings of the International Congress of Surface Activity, 1957; pp 426-438.
(31) Lin, I. J.; Marszall, L. CMC, HLB, and effective chain length of surface-active anionic and cationic substances containing oxyethylene groups. J. Colloid Interface Sci. 1976, 57, 85-93.

(32) Lin, I. J. Hydrophile-lipophile balance (hlb) of fluorocarbon surfactants and its relation to the critical micelle concentration $(\mathrm{cmc})$. J. Phys. Chem. A 1972, 76, 2019-2023.

(33) Pasquali, R. C.; Taurozzi, M. P.; Bregni, C. Some considerations about the hydrophilic-lipophilic balance system. Int. J. Pharm. 2008, 356, 44-51.

(34) Pos, K. M.; Diederichs, K. Purification, crystallization and preliminary diffraction studies of AcrB, an inner-membrane multidrug efflux protein. Acta Crystallogr., Sect. D: Biol. Crystallogr. 2002, $58,1865-1867$.

(35) Dimasi, N.; Flot, D.; Dupeux, F.; Márquez, J. A. Expression, crystallization and X-ray data collection from microcrystals of the extracellular domain of the human inhibitory receptor expressed on myeloid cells IREM-1. Acta Crystallogr., Sect. F: Struct. Biol. Cryst. Commun. 2007, 63, 204-208. 